\title{
Late Cretaceous Gangdese intrusions of adakitic geochemical characteristics, SE Tibet: Petrogenesis and tectonic implications
}

\author{
Da-Ren Wen ${ }^{a}$, Sun-Lin Chung ${ }^{a}, *$, Biao Song ${ }^{b}$, Yoshiyuki Iizuka ${ }^{c}$, Huai-Jen Yang ${ }^{d}$, \\ Jianqing Ji ${ }^{\mathrm{e}}$, Dunyi Liu ${ }^{\mathrm{b}}$, Sylvain Gallet ${ }^{\mathrm{a}}$ \\ a Department of Geosciences, National Taiwan University, Taipei, Taiwan \\ b Institute of Geology, Chinese Academy of Geological Sciences, Beijing, China \\ c Institute of Earth Sciences, Academia Sinica, Taipei, Taiwan \\ d Department of Earth Sciences, National Cheng Kung University, Tainan, Taiwan \\ e School of Earth and Space Sciences, Peking University, Beijing, China
}

\section{A R T I C L E I N F O}

\section{Article history:}

Received 4 June 2007

Received in revised form

Accepted 6 February 2008

Available online 4 March 2008

\section{Keywords:}

Gangdese batholith

Granodiorite

Adakite

Lower crust melting

Tibet

\begin{abstract}
A B S T R A C T
The Gangdese batholith emplaced from the Cretaceous to Eocene in southern Tibet has been widely regarded as the major constituent of an Andean-type convergent margin resulting from northward subduction of the Neo-Tethyan oceanic lithosphere under Asia. While the Gangdese batholith consists predominantly of calcalkaline rocks, we identify from the eastern part of the batholith a suite of epidote-bearing granodiorites that shows adakitic geochemical characteristics, marked with apparently higher $\mathrm{La} / \mathrm{Yb}$ and $\mathrm{Sr} / \mathrm{Y}$, and lower $\mathrm{Y}$ and HREE, than other Gangdese rocks and common arc magmas. SHRIMP zircon U-Pb analyses of two of the samples yielded ${ }^{206} \mathrm{~Pb} /{ }^{238} \mathrm{U}$ dates of $80.4 \pm 1.1$ and $82.7 \pm 1.6(2 \sigma)$ Ma, which constrain the emplacement ages of the adakitic rocks. Trace element modeling suggests that these rocks originated from partial melting of a garnet amphibolite source that, on the basis of the $\mathrm{Sr}$ and $\mathrm{Nd}$ isotope data $\left[\mathrm{I}_{\mathrm{Sr}}=0.7044-0.7048 ; \varepsilon_{\mathrm{Nd}}(T)=+3.2\right.$ to +0.9 ], we interpret to be a newly underplated, mafic lower crust, rather than the subducted Neo-Tethyan oceanic crust. This juvenile crust was produced by Cretaceous basaltic underplating above the mantle wedge and then thickened by the tectonic contraction owing to flattening of the Neo-Tethyan subduction, a process that also led to the adakitic magmatism. Our interpretation involving a Late Cretaceous flat-slab subduction and related orogenesis in southern Tibet is consistent with petrographic data, such as the occurrence of magmatic epidote and muscovite rimmed with resorption texture in the granodiorites, which indicate deepseated emplacement followed by rapid tectonic exhumation.
\end{abstract}

(c) 2008 Elsevier B.V. All rights reserved.

\section{Introduction}

In southern Tibet, the elongated belt of granitoids that occurs in the Lhasa terrane north of the Yarlu-Zangpo suture zone (Fig. 1) has been termed the "Trans-Himalayan Batholith" (cf. Searle et al., 1987; and references therein) and regarded as a principal component of the Andean-type continental margin along South Asia resulting from northward subduction of the Neo-Tethyan oceanic lithosphere before the India-Asia collision (Allegrè et al., 1984; Yin and Harrison, 2000). Previous studies (e.g., Debon et al., 1986; Searle et al., 1987; Harris et al., 1988; TBGMR, 1993; Mo et al., 2005) indicated that the granitoids consist actually of a wide range of compositions from gabbro to granite, and the most abundant rock type is hornblende-biotitebearing diorite and granodiorite that are geochemically comparable to the I-type calc-alkaline granitoids emplaced in the circum-Pacific regions (Chappell and White, 1974; Pitcher, 1982). As part of our study

* Corresponding author. Department of Geosciences, National Taiwan University, P. O. Box 13-318, Taipei 10699, Taiwan. Fax: +886 223636095.

E-mail address: sunlin@ntu.edu.tw (S.-L. Chung). of the Trans-Himalayan magmatism, we describe in this paper a recently discovered suite of epidote-bearing granodiorites, characterized by adakitic geochemical affinities, from the eastern part of the Gangdese batholith, one of the largest intrusive bodies in southern Tibet. We report SHRIMP (sensitive high resolution ion microprobe) zircon $\mathrm{U}-\mathrm{Pb}$ ages, mineralogical, major and trace element, and $\mathrm{Sr}-\mathrm{Nd}$ isotope data for these rocks that suggest a magmatic origin by partial melting of a newly underplated and thickened mafic lower crust above the mantle wedge at ca. $80 \mathrm{Ma}$, when the Neo-Tethyan subduction was flattened. This study bears important implications for not only the petrogenesis of subduction-related adakitic magmatism in general, but also the precollisional tectonomagmatic evolution in southern Tibet where "collision-type" adakites were emplaced from the Late Oligocene to Middle Miocene after India started colliding with Asia (e.g., Chung et al., 2003; Hou et al., 2004; Guo et al., 2007).

\section{Background}

Tibet is essentially composed of four continental blocks or terranes that, from north to south, are the Songpan-Ganze, Qiangtang, Lhasa 


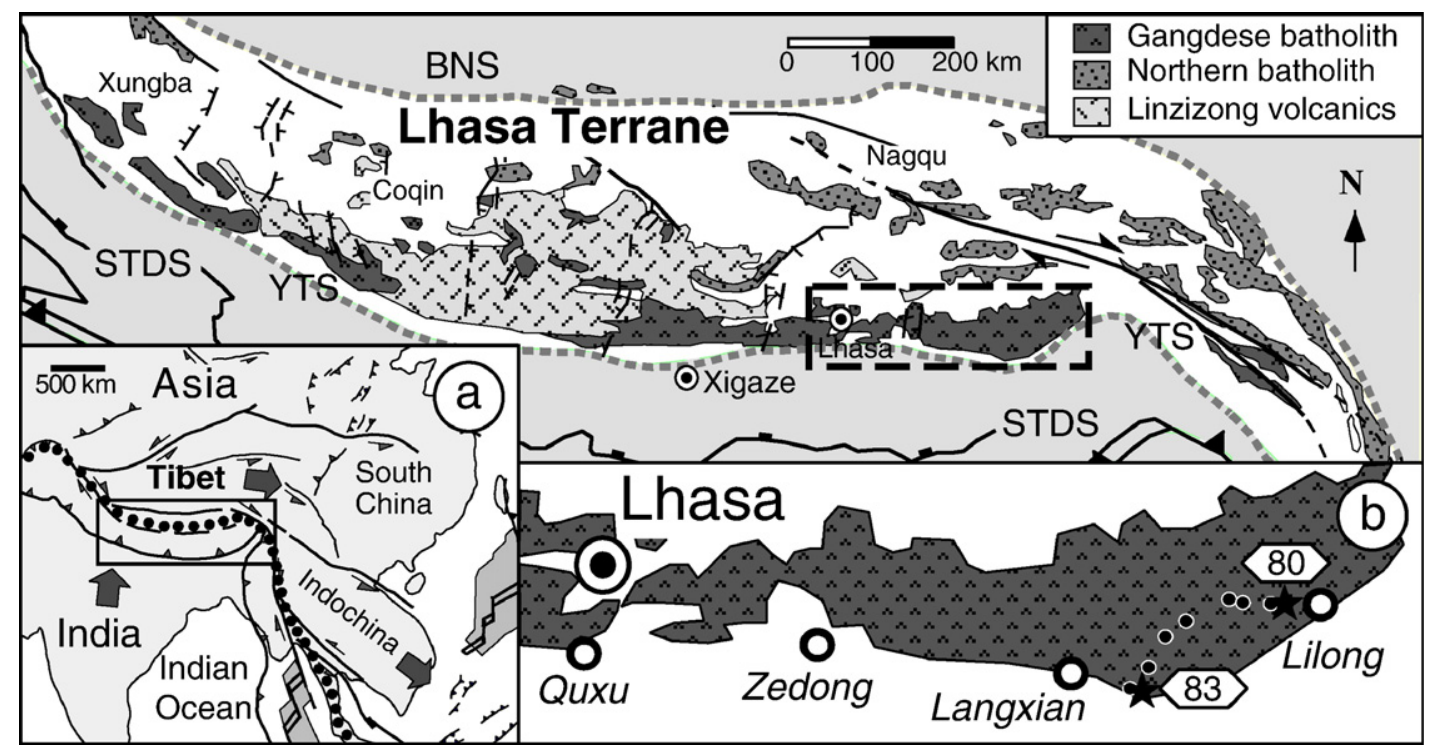

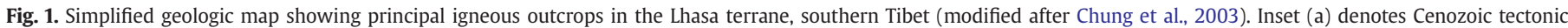

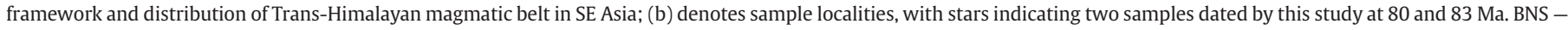
Bangong-Nujiang suture; YTS - Yarlu-Tsangpo suture; STDS - South Tibet detachment system.

and Tethyan Himalaya, separated by the Jinsha, Bangong-Nujiang and Yarlu-Tsangpo suture zones representing Paleo-, Meso- and NeoTethyan oceanic relicts, respectively (cf. Yin and Harrison, 2000). The Lhasa terrane, which dispersed from Gondwana and then drifted northward and finally amalgamated with the Qiangtang terrane in the Early Cretaceous (Kapp et al., 2005), consists primarily of Paleozoic to Paleogene sedimentary strata and associated igneous rocks (Yin and Harrison, 2000). The latter include the Linzizong volcanic successions and the widespread Trans-Himalayan intrusive bodies that have been divided into two suites (Fig. 1): a southern Gangdese belt dominated by dioritic and I-type compositions (Debon et al., 1986; Harris et al., 1988; TBGMR, 1993; Wen et al., 2003, 2004) and a northern plutonic belt comprised largely of peraluminous, or S-type, granitoids (Xu et al., 1985; Harris et al., 1988, 1990).

The duration of the Gangdese magmatism was previously constrained using $\mathrm{Ar}-\mathrm{Ar}$ (e.g., Maluski et al., 1982; Copeland et al., 1995; Harrison et al., 2000), Rb-Sr (Debon et al., 1982; Jin and Xu, 1984; Xu et al., 1985) and zircon U-Pb age data (Schärer et al., 1984; Xu et al., 1985; Quidelleur et al., 1997; Mo et al., 2005). Most recently, based on a more detailed investigation of the Gangdese batholith, Wen et al. (in press) reported new SHRIMP zircon U-Pb ages of 25 samples that, together with the literature data, suggest two distinct stages of Gangdese magmatism in the Late Cretaceous (ca.103-80 Ma) and early Paleogene (ca. 68-43 Ma), with a magmatic gap or quiescent period in between. Additionally, Chu et al. (2006) identified an early Jurassic, previously uncomprehended stage of Gangdese intrusion that implies that Neo-Tethyan subduction played a long-lasting role in the tectonic evolution of southern Tibet prior to the closure of NeoTethys Ocean and the start of the India-Asia collision. In this study, we document the emplacement age and geochemical characteristics of a suite of Late Cretaceous adakitic intrusion in the eastern part of the Gangdese batholith and explore its petrogenesis and significance to the regional tectonics.

\section{Occurrence and samples}

The studied area is located between Langxian and Lilong in the eastern Gangdese batholith (Fig. 1). Here intrusive rocks generally show median-grained and equigranular texture, with remarkably different mineral assemblages from other Gangdese granitoids. They are epidote-muscovite-bearing, consist mainly of plagioclase, Kfeldspar, quartz and biotite, but lack hornblende and/or pyroxene that are common in the calc-alkaline Gangdese rocks. In some areas the intrusion is cut and deformed by the Renbu-Zedong Thrust, which Quidelleur et al. (1997) reported thermochronological data for suggesting Miocene thrusting activity. Quidelleur et al. (1997) also conducted ion microprobe analyses of zircon separates from the hanging wall granitoids that gave ${ }^{206} \mathrm{~Pb} /{ }^{238} \mathrm{U}$ ages dominantly between ca. 80 and $100 \mathrm{Ma}$, indicating that the intrusion took place around the Late Cretaceous.

In this study, nine granodiorite samples were collected along the main road between Langxian and Lilong (Fig. 1). They are generally fresh, without visible alteration, and medium- to coarse-grained rocks, composed mainly of plagioclase, K-feldspar, quartz and biotite. Accessory phases include apatite, zircon, epidote, titanite, muscovite, Fe-Ti oxides, allanite and rutile. Two samples, T024 and T027, from the eastern and western parts of the sampling sites (Fig. 1), were subjected to zircon separation for SHRIMP U-Pb dating. We note that sample T027 was actually collected from a locality within the area studied by Quidelleur et al. (1997).

\section{Analytical methods}

Zircons were separated by heavy-liquid and magnetic methods. Insitu zircon $\mathrm{U}-\mathrm{Pb}$ dating was carried out using the SHRIMP II at the Beijing SHRIMP Lab, the Chinese Academy of Geological Sciences, with analytical conditions following those reported in Liu et al. (2006) and Wen et al. (in press). $\mathrm{U}-\mathrm{Th}-\mathrm{Pb}$ isotope ratios were measured relative to the zircon standard TEMORA (Black et al., 2003).

Electron microprobe analyses on minerals were performed on polished thin sections at the Institute of Earth Sciences, Academia Sinica, Taipei, using a JXA®-8900R electron probe microanalyzer. Analyses were performed in wavelength dispersive mode with $15 \mathrm{keV}$ accelerating voltage, $5 \mathrm{nA}$ beam current and $1 \mu \mathrm{m}$ spot diameter. More analytical conditions have been reported in Xu et al. (2004).

Powdered samples were analyzed for major elements by X-ray fluorescence (XRF) using a Rigaku® RIX 2000 spectrometer at the Department of Geosciences, National Taiwan University. The analytical 
Table 1

SHRIMP zircon U-Pb data of the granodiorites from SE Tibet

\begin{tabular}{|c|c|c|c|c|c|c|c|}
\hline \multirow[t]{2}{*}{ Sample } & \multirow{2}{*}{$\frac{\mathrm{U}}{(\mathrm{ppm})}$} & \multirow{2}{*}{$\frac{\mathrm{Th}}{(\mathrm{ppm})}$} & \multirow[t]{2}{*}{$\mathrm{Th} / \mathrm{U}$} & \multirow{2}{*}{$\frac{f_{206}}{(\%)}$} & \multirow{2}{*}{$\frac{{ }^{206} \mathrm{~Pb}^{*} /{ }^{238} \mathrm{U}}{( \pm 1 \sigma)}$} & \multirow{2}{*}{$\frac{{ }^{207} \mathrm{~Pb} *{ }^{235} \mathrm{U}}{( \pm 1 \sigma)}$} & \multirow{2}{*}{$\frac{{ }^{206} \mathrm{~Pb}^{*} /{ }^{238} \mathrm{U} \text { age }}{(\mathrm{Ma} \pm 1 \sigma)}$} \\
\hline & & & & & & & \\
\hline \multicolumn{8}{|l|}{ Т024 } \\
\hline 1.1 & 121 & 96 & 0.80 & 2.80 & $0.01221 \pm 0.00023$ & $0.0425 \pm 0.0093$ & $78.2 \pm 1.5$ \\
\hline 2.1 & 789 & 400 & 0.51 & 0.10 & $0.01247 \pm 0.00017$ & $0.0808 \pm 0.0026$ & $79.9 \pm 1.1$ \\
\hline 3.1 & 359 & 282 & 0.78 & 0.23 & $0.01248 \pm 0.00018$ & $0.0814 \pm 0.0040$ & $79.9 \pm 1.2$ \\
\hline 4.1 & 393 & 180 & 0.46 & 0.13 & $0.01268 \pm 0.00018$ & $0.0829 \pm 0.0049$ & $81.2 \pm 1.2$ \\
\hline 5.1 & 934 & 515 & 0.55 & 0.43 & $0.01245 \pm 0.00017$ & $0.0783 \pm 0.0030$ & $79.7 \pm 1.1$ \\
\hline 6.1 & 193 & 121 & 0.63 & 2.65 & $0.01282 \pm 0.00035$ & $0.0490 \pm 0.0136$ & $82.1 \pm 2.2$ \\
\hline 7.1 & 1288 & 471 & 0.37 & -0.02 & $0.01313 \pm 0.00017$ & $0.0889 \pm 0.0019$ & $84.1 \pm 1.1$ \\
\hline 8.1 & 340 & 249 & 0.73 & 0.47 & $0.01241 \pm 0.00018$ & $0.0749 \pm 0.0055$ & $79.5 \pm 1.2$ \\
\hline 9.1 & 156 & 65 & 0.42 & 0.29 & $0.01220 \pm 0.00023$ & $0.0774 \pm 0.0125$ & $78.2 \pm 1.5$ \\
\hline 10.1 & 452 & 351 & 0.78 & -0.11 & $0.01282 \pm 0.00018$ & $0.0856 \pm 0.0026$ & $82.1 \pm 1.1$ \\
\hline 11.1 & 674 & 364 & 0.54 & -0.02 & $0.01232 \pm 0.00017$ & $0.0811 \pm 0.0024$ & $78.9 \pm 1.1$ \\
\hline 12.1 & 443 & 366 & 0.83 & 0.51 & $0.01249 \pm 0.00018$ & $0.0795 \pm 0.0044$ & $80.0 \pm 1.1$ \\
\hline Weighted mean $(2 \sigma)$ & & & & & & & $80.4 \pm 1.1$ \\
\hline \multicolumn{8}{|l|}{ T027 } \\
\hline 1.1 & 71 & 40 & 0.56 & 4.32 & $0.01272 \pm 0.00043$ & $0.0688 \pm 0.0096$ & $81.5 \pm 3.3$ \\
\hline 4.1 & 21 & 12 & 0.56 & 18.41 & $0.01314 \pm 0.00060$ & $0.0161 \pm 0.0647$ & $84.2 \pm 6.4$ \\
\hline 5.1 & 151 & 106 & 0.70 & 3.21 & $0.01280 \pm 0.00038$ & $0.0851 \pm 0.0102$ & $82.0 \pm 2.9$ \\
\hline 6.1 & 184 & 119 & 0.65 & 2.70 & $0.01275 \pm 0.00038$ & $0.0810 \pm 0.0065$ & $81.7 \pm 2.9$ \\
\hline 7.1 & 158 & 85 & 0.54 & 1.99 & $0.01342 \pm 0.00039$ & $0.0855 \pm 0.0060$ & $85.9 \pm 2.8$ \\
\hline 9.1 & 364 & 342 & 0.94 & 1.85 & $0.01266 \pm 0.00035$ & $0.0717 \pm 0.0050$ & $81.1 \pm 2.7$ \\
\hline 11.1 & 63 & 39 & 0.62 & 7.72 & $0.01229 \pm 0.00045$ & $0.0627 \pm 0.0119$ & $78.8 \pm 3.7$ \\
\hline 12.1 & 279 & 182 & 0.65 & 1.93 & $0.01315 \pm 0.00037$ & $0.0759 \pm 0.0061$ & $84.2 \pm 2.7$ \\
\hline 13.1 & 123 & 75 & 0.61 & 3.65 & $0.01345 \pm 0.00042$ & $0.0626 \pm 0.0088$ & $86.1 \pm 3.2$ \\
\hline 15.1 & 29 & 19 & 0.64 & 10.62 & $0.01152 \pm 0.00065$ & $0.0487 \pm 0.0209$ & $73.8 \pm 5.9$ \\
\hline 17.1 & 64 & 35 & 0.55 & 6.71 & $0.01285 \pm 0.00046$ & $0.0610 \pm 0.0177$ & $82.3 \pm 3.8$ \\
\hline 18.1 & 39 & 23 & 0.58 & 14.13 & $0.01233 \pm 0.00047$ & $0.0174 \pm 0.0294$ & $79.0 \pm 4.4$ \\
\hline 20.1 & 110 & 70 & 0.63 & 4.85 & $0.01274 \pm 0.00039$ & $0.0683 \pm 0.0075$ & $85.0 \pm 2.6$ \\
\hline 21.1 & 42 & 23 & 0.54 & 14.74 & $0.01188 \pm 0.00045$ & & $76.9 \pm 6.9$ \\
\hline 22.1 & 272 & 214 & 0.79 & 1.45 & $0.01347 \pm 0.00036$ & $0.0804 \pm 0.0040$ & $86.2 \pm 2.8$ \\
\hline 23.1 & 130 & 161 & 1.23 & 5.06 & $0.01348 \pm 0.00042$ & $0.0635 \pm 0.0159$ & $86.3 \pm 3.7$ \\
\hline Weighted mean $(2 \sigma)$ & & & & & & & $82.7 \pm 1.6$ \\
\hline 2.1 & 391 & 117 & 0.30 & 0.33 & $0.05385 \pm 0.00140$ & $0.3910 \pm 0.0117$ & $338.1 \pm 9.0$ \\
\hline 3.1 & 469 & 352 & 0.75 & -2.23 & $0.04157 \pm 0.00108$ & $0.4188 \pm 0.0126$ & $262.5 \pm 7.4$ \\
\hline 8.1 & 886 & 821.98 & 0.93 & 0.76 & $0.01654 \pm 0.00043$ & $0.0965 \pm 0.0039$ & $105.8 \pm 3.3$ \\
\hline 10.1 & 2005.29 & 136 & 0.07 & 0.26 & $0.01818 \pm 0.00045$ & $0.1207 \pm 0.0036$ & $116.1 \pm 3.0$ \\
\hline 14.1 & 200 & 145 & 0.73 & 2.48 & $0.01555 \pm 0.00044$ & $0.0856 \pm 0.0060$ & $99.5 \pm 3.3$ \\
\hline 16.1 & 193 & 93 & 0.48 & 1.72 & $0.01933 \pm 0.00054$ & $0.1212 \pm 0.0085$ & $123.4 \pm 3.8$ \\
\hline 19.1 & 139 & 85 & 0.61 & 3.16 & $0.01534 \pm 0.00044$ & $0.0932 \pm 0.0075$ & $98.1 \pm 3.4$ \\
\hline
\end{tabular}

uncertainties are generally better than $5 \%$ for all elements. Trace elements were measured by inductively coupled plasma mass spectrometry (ICP-MS) using an Agilent ${ }^{\circledR} 7500$ s machine in the same Department. The analytical accuracy and precision are generally better than $3 \%$. Analytical details for the major and trace element measurements may be found in Chung et al. (2003) and Yang et al. (2005).

Whole-rock $\mathrm{Sr}$ and $\mathrm{Nd}$ isotope ratios were determined using a Finnigan MAT-262 ${ }^{\circledR}$ mass spectrometer operated in static multicollector mode at the Department of Earth Sciences, National Cheng-Kung University. Measured ${ }^{87} \mathrm{Sr} /{ }^{86} \mathrm{Sr}$ and ${ }^{143} \mathrm{Nd} /{ }^{144} \mathrm{Nd}$ ratios were normalized to ${ }^{86} \mathrm{Sr} /{ }^{88} \mathrm{Sr}=0.1194$ and ${ }^{146} \mathrm{Nd} /{ }^{144} \mathrm{Nd}=0.7219$, respectively, for mass fractionation correction. During the period of data acquisition, the mean ${ }^{87} \mathrm{Sr} /{ }^{86} \mathrm{Sr}$ ratio of NBS987 standard was $0.710261 \pm 17(n=8)$ and mean ${ }^{143} \mathrm{Nd} /{ }^{144} \mathrm{Nd}$ ratio of La Jolla standard was $0.511830 \pm 12(n=12)$. Detailed chemical procedures and instrumentation specifications have been reported by Liu et al. (2007).

\section{Results}

\subsection{Zircon $U-P b$ ages}

Similar to zircon separates from other Gangdese rocks (Chu, 2006; Chu et al., 2006; Wen et al., in press), zircons of this study are mostly euhedral, with long to short prismatic shapes with average crystal lengths of $\sim 100-200 \mu \mathrm{m}$ and length-to-width ratios up to $4: 1$. Most zircons are transparent, colourless to slightly brown, and display oscillatory zoning typical of magmatic growth. Zircons with rounded or ovoid shape are, however, occasionally present in sample T027.

Zircon $\mathrm{U}-\mathrm{Pb}$ isotope data are listed in Table 1 and plotted in the concordia diagrams (Fig. 2). Owing to the youth and relatively low $\mathrm{U}$ abundance of the zircons dated, large uncertainties on ${ }^{207} \mathrm{~Pb} /{ }^{235} \mathrm{U}$ ratios and calculated ages are observed. Therefore, weighted means of pooled ${ }^{206} \mathrm{~Pb} /{ }^{238} \mathrm{U}$ ages are taken to represent the crystallization ages that are reported with uncertainties at two standard deviations $(2 \sigma)$ or $95 \%$ confidence level. A total of twelve analyses of zircons from sample T024 yielded rather uniform ${ }^{206} \mathrm{~Pb} /{ }^{238} \mathrm{U}$ ratios and a weighted mean of ${ }^{206} \mathrm{~Pb} /{ }^{238} \mathrm{U}$ ages at $80.4 \pm 1.1 \mathrm{Ma}$ (Fig. 2a). The Th and $\mathrm{U}$ concentrations range from 515 to 65 and 1288 to $121 \mathrm{ppm}$, respectively, yielding $\mathrm{Th} / \mathrm{U}$ ratios between 0.83 and 0.42 that are in good accordance with those of igneous zircons (Belousova et al., 2002). Although zircons from sample T027 are slightly more complex, 16 out of 23 analyses yielded a mean ${ }^{206} \mathrm{~Pb} /{ }^{238} \mathrm{U}$ age at $82.7 \pm 1.6 \mathrm{Ma}$ (Fig. 2b), with Th and U contents varying from 342 to 12 and 364 to $21 \mathrm{ppm}$, and $\mathrm{Th} / \mathrm{U}$ ratios from 1.23 to 0.54 . The above two U-Pb ages, statistically overlapped if considering the $2 \sigma$ analytical uncertainties, delineate an important intrusive event at ca. 83-80 Ma in this part of the Gangdese batholith. Our results, moreover, support and refine the previously published zircon $\mathrm{U}-\mathrm{Pb}$ age constraints that span between ca. 80 and $100 \mathrm{Ma}$ with an age cluster at ca. 82-86 Ma (Quidelleur et al., 1997). 

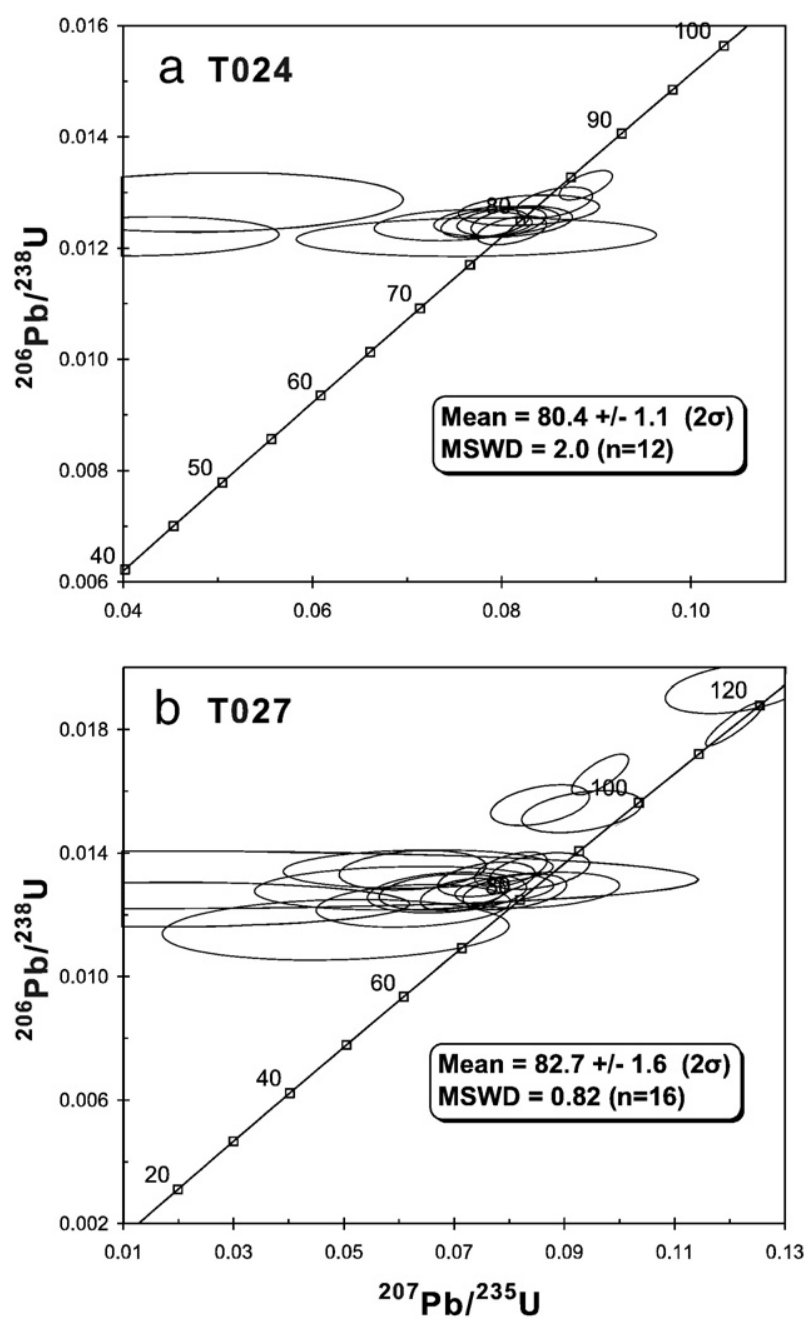

Fig. 2. Zircon U-Pb concordia diagrams of samples (a) T024 and (b) T027. Note that the mean ages shown are ${ }^{206} \mathrm{~Pb} /{ }^{238} \mathrm{U}$ ages.

In sample T027, analyses of the remaining seven zircon grains yielded older ${ }^{206} \mathrm{~Pb} /{ }^{238} \mathrm{U}$ ages between ca. 98 and $338 \mathrm{Ma}$ (Table 1). With the exception of one grain that has apparently higher $U$ content (2005 ppm) and thus low Th/U ratio (0.07), the other six grains exhibit $\mathrm{Th} / \mathrm{U}$ ratios (0.93-0.30) in the range typical of igneous zircons, and are interpreted to be inherited zircons produced by earlier magmatism in the region.

\subsection{Mineral chemistry}

As mentioned above, the rocks are characterized by the presence of magmatic epidote and muscovite as accessory phases that, along with the coexisting feldspars, bear unique petrologic significance. The compositions of these phases are sensitive to the P-T conditions of the host magma during emplacement, and therefore were carefully analyzed with the electron microprobe. Representative results on sample T024 are given in Tables 2-4.

\subsubsection{Magmatic epidote}

Epidote, which is observed in all the samples, has an average grain size of $\sim 1 \mathrm{~mm}$, similar to that of the major mineral constituents (Fig. 3, $\mathrm{a}-\mathrm{b})$. The epidote, occurring mostly as euhedral grains adjacent to biotite, occasionally shows embayed, wormy contacts with plagioclase and quartz (Fig. 3c), and often contains inclusions of phases such as allanite and/or rutile and biotite (Fig. 3d). The crystal form, resorption texture and fresh appearance of the epidote are consistent with those
Table 2

Representative electron microprobe data of epidote

\begin{tabular}{|c|c|c|c|c|c|c|c|c|}
\hline \multirow{2}{*}{$\frac{\text { Minerarl }}{\text { Analysis }}$} & \multicolumn{8}{|c|}{ Epidote $(n=40)$} \\
\hline & T-3 & $\mathrm{T}-4$ & T-7 & T-8 & $\mathrm{T}-13$ & T-14 & Mean & $\sigma$ \\
\hline $\mathrm{SiO}_{2}$ & 38.61 & 37.39 & 38.73 & 37.70 & 38.28 & 38.02 & 38.06 & 0.44 \\
\hline $\mathrm{TiO}_{2}$ & & 0.08 & 0.23 & 0.20 & 0.10 & 0.16 & 0.13 & 0.06 \\
\hline $\mathrm{Al}_{2} \mathrm{O}_{3}$ & 22.12 & 22.13 & 22.72 & 22.29 & 22.78 & 22.78 & 22.65 & 0.54 \\
\hline $\mathrm{Cr}_{2} \mathrm{O}_{3}$ & 0.03 & & 0.05 & & & & 0.01 & 0.02 \\
\hline $\mathrm{Fe}_{2} \mathrm{O}_{3}$ & 12.08 & 12.97 & 12.64 & 12.07 & 11.89 & 12.78 & 12.27 & 0.62 \\
\hline $\mathrm{MnO}$ & 0.46 & 0.51 & 0.59 & 0.64 & 0.58 & 0.56 & 0.55 & 0.08 \\
\hline $\mathrm{MgO}$ & 0.04 & 0.03 & 0.05 & 0.02 & & 0.05 & 0.02 & 0.02 \\
\hline $\mathrm{NiO}$ & & 0.01 & 0.22 & 0.11 & & 0.01 & 0.03 & 0.05 \\
\hline $\mathrm{CaO}$ & 22.34 & 23.14 & 22.80 & 23.21 & 22.72 & 22.86 & 23.06 & 0.48 \\
\hline $\mathrm{Na}_{2} \mathrm{O}$ & & & & & & & & 0.01 \\
\hline $\mathrm{K}_{2} \mathrm{O}$ & & 0.03 & 0.01 & & 0.04 & & 0.01 & 0.01 \\
\hline $\mathrm{P}_{2} \mathrm{O}_{5}$ & 0.02 & 0.03 & & & 0.02 & 0.03 & 0.02 & 0.03 \\
\hline $\mathrm{F}$ & 0.57 & 0.01 & 0.36 & & & 0.12 & 0.06 & 0.13 \\
\hline $\mathrm{Cl}$ & & & & 0.05 & 0.01 & & 0.01 & 0.01 \\
\hline Total & 96.27 & 96.33 & 98.40 & 96.29 & 96.42 & 97.37 & 96.89 & 0.96 \\
\hline \multicolumn{9}{|c|}{ Number of ions on the basis of 25 oxygens } \\
\hline $\mathrm{Si}$ & 6.40 & 6.22 & 6.30 & 6.25 & 6.30 & 6.24 & 6.26 & 0.07 \\
\hline $\mathrm{Ti}$ & & 0.01 & 0.03 & 0.03 & 0.01 & 0.02 & 0.02 & 0.01 \\
\hline Al & 4.32 & 4.34 & 4.35 & 4.36 & 4.42 & 4.41 & 4.39 & 0.08 \\
\hline $\mathrm{Cr}$ & & & 0.01 & & & & & \\
\hline $\mathrm{Fe}$ & 1.47 & 1.58 & 1.51 & 1.47 & 1.44 & 1.54 & 1.49 & 0.08 \\
\hline Mn & 0.07 & 0.07 & 0.08 & 0.09 & 0.08 & 0.08 & 0.08 & 0.01 \\
\hline $\mathrm{Mg}$ & 0.01 & 0.01 & 0.01 & & & 0.01 & & \\
\hline $\mathrm{Ni}$ & & & 0.03 & 0.01 & & & & \\
\hline $\mathrm{Ca}$ & 3.96 & 4.12 & 3.97 & 4.12 & 4.01 & 4.02 & 4.06 & 0.08 \\
\hline \multicolumn{9}{|l|}{$\mathrm{Na}$} \\
\hline $\mathrm{K}$ & & 0.01 & & & 0.01 & & & \\
\hline \multicolumn{9}{|l|}{$\mathrm{P}$} \\
\hline Ps & 26 & 27 & 26 & 26 & 25 & 26 & 25.7 & 1.3 \\
\hline
\end{tabular}

Analysis in wt.\%; total Fe measured as $\mathrm{Fe}_{2} \mathrm{O}_{3}$.

Ps: Molar Pistacite $\left[\mathrm{Fe}^{3+} /\left(\mathrm{Fe}^{3+}+\mathrm{Al}^{3+}\right) \times 100\right]$.

Table 3

Representative electron microprobe data of muscovite

\begin{tabular}{|c|c|c|c|c|c|c|c|c|}
\hline \multirow{2}{*}{$\frac{\text { Minerarl }}{\text { Analysis }}$} & \multicolumn{8}{|c|}{ Muscovite $(n=51)$} \\
\hline & $\mathrm{T} 1-23$ & $\mathrm{~T} 1-24$ & $\mathrm{~T} 1-41$ & $\mathrm{~T} 1-42$ & $\mathrm{~T} 2-01$ & $\mathrm{~T} 2-05$ & Mean & $\sigma$ \\
\hline $\mathrm{SiO}_{2}$ & 46.50 & 47.03 & 46.84 & 47.05 & 46.40 & 46.51 & 46.47 & 0.66 \\
\hline $\mathrm{TiO}_{2}$ & 1.06 & 1.17 & 1.22 & 0.56 & 0.92 & 0.80 & 0.71 & 0.24 \\
\hline $\mathrm{Al}_{2} \mathrm{O}_{3}$ & 27.39 & 28.20 & 26.85 & 27.30 & 27.32 & 28.55 & 27.91 & 0.59 \\
\hline $\mathrm{Cr}_{2} \mathrm{O}_{3}$ & & & 0.02 & & & & & \\
\hline $\mathrm{Fe}_{2} \mathrm{O}_{3}$ & 6.21 & 5.84 & 5.84 & 4.65 & 6.93 & 5.85 & 5.87 & 0.55 \\
\hline $\mathrm{MnO}$ & 0.03 & 0.10 & 0.15 & 0.05 & 0.09 & 0.04 & 0.07 & 0.05 \\
\hline $\mathrm{MgO}$ & 2.09 & 2.01 & 2.25 & 2.11 & 2.26 & 1.95 & 2.15 & 0.20 \\
\hline $\mathrm{NiO}$ & 0.20 & & 0.09 & 0.17 & & & 0.01 & 0.04 \\
\hline $\mathrm{CaO}$ & & & & 0.03 & 0.03 & & 0.02 & 0.02 \\
\hline $\mathrm{Na}_{2} \mathrm{O}$ & 0.25 & 0.24 & 0.20 & 0.21 & 0.25 & 0.26 & 0.24 & 0.04 \\
\hline $\mathrm{K}_{2} \mathrm{O}$ & 10.60 & 10.92 & 11.25 & 11.06 & 10.28 & 11.17 & 11.00 & 0.28 \\
\hline $\mathrm{P}_{2} \mathrm{O}_{5}$ & & & 0.10 & 0.01 & & & & \\
\hline $\mathrm{F}$ & 0.26 & & & 0.04 & & & 0.11 & 0.15 \\
\hline $\mathrm{Cl}$ & & 0.01 & & & & 0.03 & 0.01 & 0.01 \\
\hline Total & 94.59 & 95.52 & 94.80 & 93.25 & 94.48 & 95.16 & 94.58 & 0.84 \\
\hline \multicolumn{9}{|c|}{ Number of ions on the basis of 11 oxygens } \\
\hline $\mathrm{Si}$ & 3.23 & 3.22 & 3.24 & 3.28 & 3.18 & 3.17 & 3.19 & 0.03 \\
\hline $\mathrm{Ti}$ & 0.06 & 0.06 & 0.06 & 0.03 & 0.05 & 0.04 & 0.04 & 0.01 \\
\hline $\mathrm{Al}$ & 2.24 & 2.27 & 2.19 & 2.24 & 2.21 & 2.29 & 2.26 & 0.04 \\
\hline \multicolumn{9}{|c|}{$\mathrm{Cr}$} \\
\hline $\mathrm{Fe}$ & 0.36 & 0.33 & 0.34 & 0.27 & 0.36 & 0.30 & 0.31 & 0.03 \\
\hline $\mathrm{Mn}$ & & 0.01 & & & 0.01 & & & \\
\hline $\mathrm{Mg}$ & 0.22 & 0.20 & 0.23 & 0.22 & 0.23 & 0.20 & 0.22 & 0.02 \\
\hline $\mathrm{Ni}$ & 0.01 & & 0.01 & 0.01 & & & & \\
\hline \multicolumn{9}{|l|}{$\mathrm{Ca}$} \\
\hline $\mathrm{Na}$ & 0.03 & 0.03 & 0.03 & 0.03 & 0.03 & 0.03 & 0.03 & 0.01 \\
\hline K & 0.94 & 0.95 & 0.99 & 0.98 & 0.90 & 0.97 & 0.96 & 0.03 \\
\hline$P$ & & & 0.01 & & & & & \\
\hline $\mathrm{P}$ (kbar) at $765{ }^{\circ} \mathrm{C}$ & 9.6 & 9.3 & 10.0 & 11.0 & 8.3 & 8.0 & 8.5 & 0.9 \\
\hline
\end{tabular}

Analysis in wt.\%; total Fe measured as $\mathrm{Fe}_{2} \mathrm{O}_{3}$.

Crystallization pressure $(P)$ calculated using the equation of Anderson (1996). 
Table 4

Representative electron microprobe data of feldspar

\begin{tabular}{|c|c|c|c|c|c|c|c|c|c|c|c|c|c|}
\hline \multirow{2}{*}{$\begin{array}{l}\text { Minerarl } \\
\text { Analysis }\end{array}$} & \multicolumn{6}{|c|}{ Plagiclase (oligoclase) } & \multicolumn{4}{|c|}{ Plagiclase (albite) } & \multicolumn{3}{|c|}{ Orthoclase } \\
\hline & $\mathrm{T} 2-12$ & $\mathrm{~T} 2-45$ & $\mathrm{~T} 2-46$ & T1b-76 & T2b-41 & $\mathrm{T} 2 \mathrm{~b}-42$ & $\mathrm{~T} 2-43$ & $\mathrm{~T} 2-44$ & T1b-74 & T2b-47 & $\mathrm{T} 2-1$ & $\mathrm{~T} 2-2$ & $\mathrm{~T} 2-5$ \\
\hline $\mathrm{SiO}_{2}$ & 61.54 & 63.10 & 62.32 & 61.52 & 61.59 & 61.72 & 68.40 & 68.76 & 68.57 & 67.62 & 64.83 & 63.39 & 66.41 \\
\hline $\mathrm{TiO}_{2}$ & 0.04 & 0.06 & 0.02 & 0.01 & 0.08 & & 0.03 & & & 0.09 & 0.08 & & 0.02 \\
\hline $\mathrm{Al}_{2} \mathrm{O}_{3}$ & 23.79 & 22.66 & 23.07 & 23.59 & 23.68 & 23.46 & 19.86 & 19.66 & 19.47 & 20.14 & 18.19 & 18.28 & 18.15 \\
\hline $\mathrm{Cr}_{2} \mathrm{O}_{3}$ & & & & & & & & 0.02 & & & 0.01 & & \\
\hline $\mathrm{Fe}_{2} \mathrm{O}_{3}$ & 0.09 & & & 0.02 & 0.05 & 0.15 & & & 0.19 & 0.13 & & 0.02 & \\
\hline $\mathrm{MnO}$ & & & & & & 0.02 & 0.01 & & & 0.02 & 0.02 & & \\
\hline $\mathrm{MgO}$ & & 0.02 & 0.02 & & & & & & & & & & \\
\hline $\mathrm{NiO}$ & 0.06 & 0.10 & & & & & & 0.11 & 0.05 & 0.05 & 0.03 & 0.01 & \\
\hline $\mathrm{CaO}$ & 5.72 & 5.11 & 5.00 & 5.83 & 5.75 & 5.87 & 0.96 & 0.32 & 0.55 & 0.85 & & 0.01 & \\
\hline $\mathrm{Na}_{2} \mathrm{O}$ & 8.41 & 8.99 & 8.41 & 8.27 & 8.78 & 8.84 & 11.03 & 11.35 & 11.11 & 11.69 & 0.54 & 0.44 & 0.60 \\
\hline $\mathrm{K}_{2} \mathrm{O}$ & 0.28 & 0.07 & 0.09 & 0.26 & 0.17 & 0.25 & 0.07 & 0.06 & 0.09 & 0.05 & 16.13 & 15.90 & 16.18 \\
\hline $\mathrm{P}_{2} \mathrm{O}_{5}$ & 0.07 & 0.01 & 0.04 & & & & & 0.01 & & & 0.05 & & 0.08 \\
\hline $\mathrm{F}$ & & & 0.12 & 0.05 & & 0.15 & 0.15 & 0.07 & 0.11 & 0.27 & & & \\
\hline $\mathrm{Cl}$ & 0.01 & & 0.03 & & & & & & & 0.01 & 0.02 & & \\
\hline Total & 100.00 & 100.13 & 99.11 & 99.56 & 100.10 & 100.45 & 100.51 & 100.36 & 100.14 & 100.87 & 99.90 & 98.06 & 101.44 \\
\hline \multicolumn{14}{|c|}{ Number of ions on the basis of 32 oxygens } \\
\hline $\mathrm{Si}$ & 10.95 & 11.17 & 11.13 & 8.58 & 10.95 & 10.97 & 11.91 & 11.97 & 11.98 & 11.80 & 12.00 & 11.95 & 12.08 \\
\hline $\mathrm{Ti}$ & 0.01 & 0.01 & & & 0.01 & & & & & 0.01 & 0.01 & & \\
\hline $\mathrm{Al}$ & 4.99 & 4.73 & 4.86 & 3.88 & 4.96 & 4.91 & 4.08 & 4.03 & 4.01 & 4.14 & 3.97 & 4.06 & 3.89 \\
\hline \multicolumn{14}{|l|}{$\mathrm{Cr}$} \\
\hline $\mathrm{Fe}$ & 0.01 & & & & 0.01 & 0.02 & & & 0.03 & 0.02 & & & \\
\hline \multicolumn{14}{|l|}{ Mn } \\
\hline $\mathrm{Mg}$ & & 0.01 & & & & & & & & & & & \\
\hline $\mathrm{Ni}$ & 0.01 & 0.01 & & & & & & 0.02 & 0.01 & & 0.01 & & \\
\hline $\mathrm{Ca}$ & 1.09 & 0.97 & 0.96 & 0.87 & 1.09 & 1.12 & 0.18 & 0.06 & 0.10 & 0.16 & & & \\
\hline $\mathrm{Na}$ & 2.90 & 3.08 & 2.91 & 2.24 & 3.03 & 3.04 & 3.72 & 3.83 & 3.76 & 3.95 & 0.19 & 0.16 & 0.21 \\
\hline K & 0.06 & 0.02 & 0.02 & 0.05 & 0.04 & 0.06 & 0.02 & 0.01 & 0.02 & 0.01 & 3.81 & 3.82 & 3.75 \\
\hline $\mathrm{P}$ & 0.01 & & 0.01 & & & & & & & & 0.01 & & 0.01 \\
\hline $\mathrm{Ab}(\mathrm{mol} \%)$ & 71.6 & 75.8 & 74.9 & 70.9 & 72.8 & 72.2 & 95.0 & 98.1 & 96.8 & 95.9 & 4.8 & 4.1 & 5.3 \\
\hline An (mol\%) & 26.9 & 23.8 & 24.6 & 27.6 & 26.3 & 26.5 & 4.6 & 1.5 & 2.7 & 3.8 & 0.0 & 0.1 & 0.0 \\
\hline Or (mol\%) & 1.6 & 0.4 & 0.5 & 1.4 & 0.9 & 1.3 & 0.4 & 0.3 & 0.5 & 0.3 & 95.2 & 95.9 & 94.7 \\
\hline
\end{tabular}

Analysis in wt.\%; total Fe measured as $\mathrm{Fe}_{2} \mathrm{O}_{3}$.

of primary epidote of magmatic origin (cf. Zen and Hammastrom, 1984; Schmidt and Poli, 2004). In addition, the edipotes we analyzed have low $\mathrm{TiO}_{2}(<0.2 \mathrm{wt} . \%)$ and restricted pistacite (Ps) contents, i.e., atomic $\mathrm{Fe}^{3+} /\left(\mathrm{Fe}^{3+}+\mathrm{Al}^{3+}\right)$, between $23 \%$ and $28 \%$ (Fig. 4), that are compatible with primary epidotes reported in the South American (Sial et al., 1999) and North American Cordilleras (Zen and Hammastrom, 1984; Barth, 1990; Brandon et al., 1996), and match the chemical criteria of magmatic epidotes (Zen and Hammastrom, 1984; Schmidt and Poli, 2004).

\subsection{Celadonitic muscovite}

Muscovite, with a grain size from $\sim 0.3$ to $>1 \mathrm{~mm}$ in length (Fig. 3a), often occurs in association with epidote as an euhedral phase that occasionally is resorbed by quartzo-feldspathic matrix (Fig. 3c). Microprobe analyses (Table 3 ) indicate that this phase has high $\mathrm{TiO}_{2}$ content (from 0.3 to 1.2 wt.\%), typical of magmatic muscovite (>0.4 wt.\%; Anderson, 1996). The high celadonitic components (i.e., the amount of $\mathrm{Mg}$ and $\mathrm{Fe}$ that substitutes for $\mathrm{Al}$ in the octahedral site, and $\mathrm{Si}$ that substitutes for $\mathrm{Al}$ in the tetrahedral site) observed here are also typical of primary muscovite in peraluminous granitoids reported elsewhere (Barth, 1990; Anderson, 1996).

\subsection{Feldspar}

Plagioclase and K-feldspar are common, with the former being the most abundant, in the rocks (Fig. 3, a-b). While K-feldspar of orthoclase composition $(\mathrm{Or} \approx 95)$ is typical, there are two generations of plagioclase composed of oligoclase $\left(A n_{24}-A n_{28}\right)$ and albite $\left(A n_{2-}\right.$ $\mathrm{An}_{5}$ ) (Table 4). Petrographic evidence shows that oligoclase is the main crystalline phase, while albite crystallized along with quartz from incongruent melts of the oligoclase's margins at a later stage (Fig. 3e). In addition, the late-stage phase of quartz occasionally occurs as droplets along the boundaries of orthoclase and muscovite (Fig. 3f). These disequilibrium textures, together with the above-described resorption features rimming epidote and muscovite, imply that the minerals crystallized under unstable conditions at depth, and then underwent decompressional melting along crystal margins owing to rapid upward transport (Nelson and Montana, 1992).

\subsection{Major and trace elements}

Whole-rock major and trace element data are presented in Table 5. The rocks show uniform major element compositions, with $\mathrm{SiO}_{2}$ contents of $\sim 65-70 \mathrm{wt} . \%$ and $\mathrm{Al}_{2} \mathrm{O}_{3}$ of $\sim 16-18 \mathrm{wt} . \%$. With the exception of sample T212 (which has higher $\mathrm{K}_{2} \mathrm{O}$ of $\sim 3 \mathrm{wt} . \%$ ), these granodiorites are medium-K in nature, with $\mathrm{Na}_{2} \mathrm{O}>4.1$ wt.\% and $\mathrm{Na}_{2} \mathrm{O} / \mathrm{K}_{2} \mathrm{O}>2$. In comparison with other Gangdese rocks that range from gabbro to granite, they all are peraluminous, with $\mathrm{A} / \mathrm{CNK}$ values, i.e., molar $\mathrm{Al}_{2} \mathrm{O}_{3} /\left(\mathrm{CaO}+\mathrm{Na}_{2} \mathrm{O}+\mathrm{K}_{2} \mathrm{O}\right),>1.0$ (Fig. 5) and have low $\mathrm{MgO}$ (<1.0 wt.\%) or $\mathrm{Mg \#}$ ( 37-31).

More interestingly, the rocks exhibit strongly fractionated rare earth element (REE) patterns (Fig. 6) characterized by high $(\mathrm{La} / \mathrm{Yb})_{\mathrm{N}}$ ratios ( 42-9; Table 5) and low heavy REE (HREE; e.g., $\mathrm{Yb}=0.4-$ $1.1 \mathrm{ppm}$ ) and $\mathrm{Y}$ contents ( 4-12 ppm) that are distinctly different from other Gangdese rocks or the "normal" calc-alkaline arc lavas (Figs. 6 and 7). In addition, these rocks contain high $\mathrm{Sr}$ contents ( 780$620 \mathrm{ppm}$ ), leading to high Sr/Y ratios ( 200-60; Table 5). All such elemental characteristics, in particular elevated $\mathrm{Sr} / \mathrm{Y}$ and $\mathrm{La} / \mathrm{Yb}$ ratios (Fig. 8), are discriminating features observed in adakites from the circum-Pacific subduction zones (Defant and Drummond, 1990; Martin, 1999). Hence, we conclude that the peraluminous 

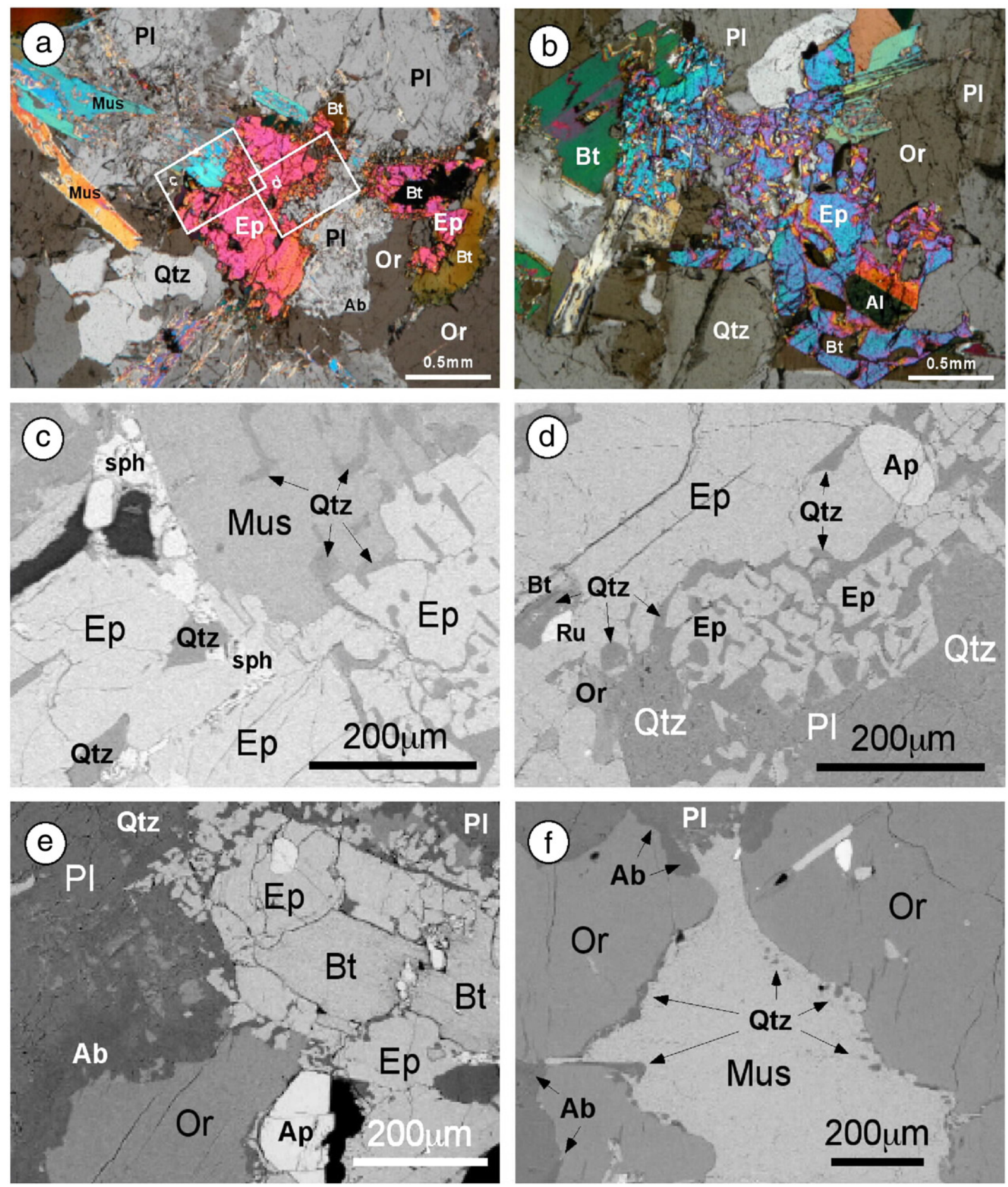

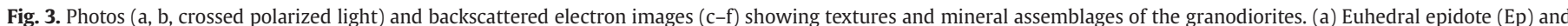

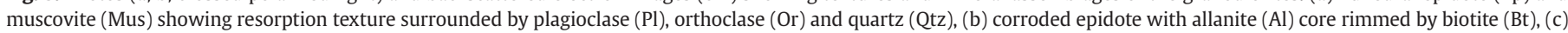

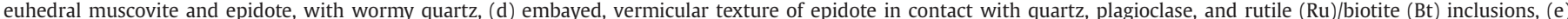

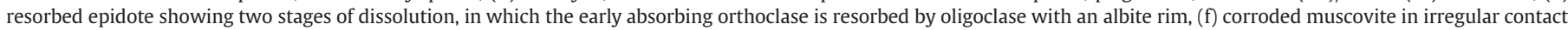
with orthoclase and plagioclase rimmed by albite, arrows denote droplets of quartz that form along boundaries of muscovite and orthoclase.

granodiorites of this study are marked by adakitic geochemical compositions, and refer to them hereafter as "the Gangdese adakites".

\subsection{Sr-Nd isotopes}

Sr and Nd isotope results of the Gangdese adakites are also listed in Table 5 . As a whole, they show slightly lower $\varepsilon_{\mathrm{Nd}}(T)$ values (+3.0 to
$+0.9)$ and higher initial ${ }^{87} \mathrm{Sr} /{ }^{86} \mathrm{Sr}$ ratios $(\sim 0.7044$ to 0.7048$)$ than the Cretaceous Gangdese calc-alkaline granitoids that are characterized by juvenile mantle isotopic signatures (Fig. 9). This implies that the adakitic magma generation involved a slightly higher extent of assimilation of material of the continental crust, relative to the associated calc-alkaline magmas. However, in light of their positive $\varepsilon_{\mathrm{Nd}}(T)$ values, and thus younger $\mathrm{Nd}$ model ages or average crustal 


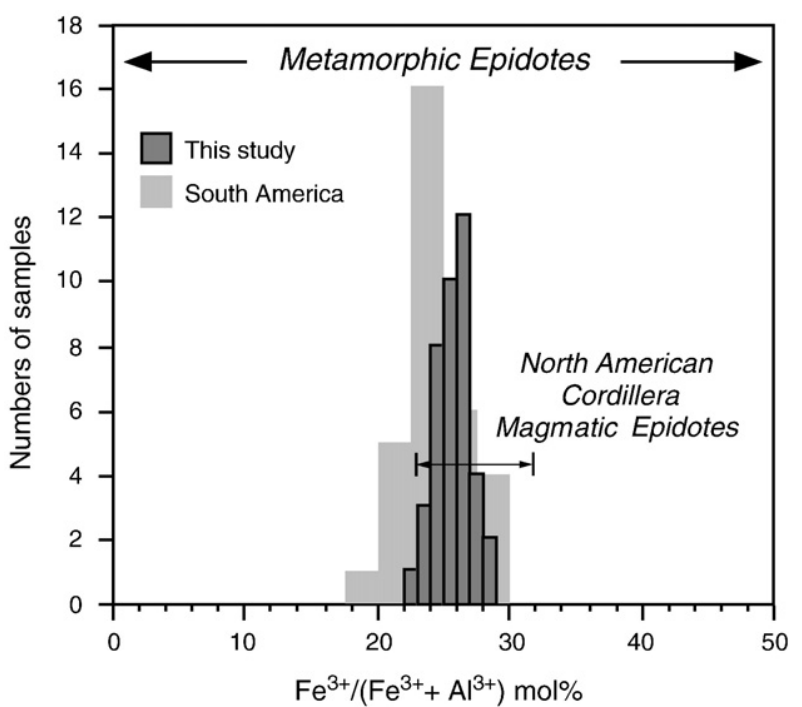

Fig. 4. Histogram of pistacite (Ps) contents of epidote. Comparison data of magmatic and metamorphic epidotes are from Zen and Hammastrom (1984), Barth (1990), Brandon et al. (1996) and Sial et al. (1999).

residence time (i.e., $\mathrm{T}_{\mathrm{DM}}=0.51-0.80 \mathrm{Ga}$; Table 5), the juvenile mantle component must have also played an important role in the petrogenesis of the Gangdese adakites.

\section{Discussion}

\subsection{Magma source - Sr and Nd isotopic constraints}

In subduction zones, as exemplifed by the Andes (Kay and Kay, 2002), there are three ways to form adakitic magmas given the consensus that a mafic source containing garnet and/or amphibole as the residual phases is required (cf. Rapp et al., 1991). The magma generation involves three candidate sources that are subducting oceanic crust (Defant and Drummond, 1990; Martin, 1999), underplated and thickened basaltic lower crust above the mantle wedge (Atherton and Petford, 1993; Kay and Kay, 1993), and subductioneroded forearc continental crust (Kay and Mpodozis, 2001). These distinct sources may be delineated using isotope compositions of the adakitic magmas.

As illustrated in Fig. 9, $\mathrm{Sr}$ and Nd isotope ratios of the Gangdese adakites preclude them from any direct genetic links with the NeoTethyan oceanic crust and subduction erosion related processes. Moreover, the low Mg\# values ( 31-37) and low Ni (0.4-5.8 ppm) and $\mathrm{Cr}(<11.4 \mathrm{ppm})$ contents of the Gangdese adakites differ markedly from those of slab-derived adakitic melts (Mg\#> 47; Martin, 1999; Smithies, 2000) that would normally interact with the mantle wedge peridotite during magma ascent. Note that in Fig. 9 we assume the isotopic composition of the subducted oceanic slab to be similar to that of the Neo-Tethyan ophiolites from the Yarlu Tsangpo suture zone (Xu and Castillo, 2004; Zhang et al., 2005). These ophiolitic rocks have high positive $\varepsilon_{\mathrm{Nd}}(T)$ values ( $\geq+8$, except one analysis around +6 ), indicating the depleted mantle nature within the Neo-Tethyan asthenosphere (Xu and Castillo, 2004; Zhang et al., 2005). If melting occurred during subduction of this kind of oceanic crust, the melts generated would require a large amount of mixing with the continental crust $(>15-20 \%$ ) to form the $\mathrm{Sr}-\mathrm{Nd}$ isotope ratios observed in the Gangdese adakites. This is considered very unlikely because such high degrees of crustal contamination should significantly change the compositions of the slab melts and thus their trace element characteristics (e.g., the high $\mathrm{La} / \mathrm{Yb}$ and $\mathrm{Sr} / \mathrm{Y}$ ratios) would become indistinct or even disappear.
The Gangdese adakites, in fact, show a resemblance to the associated calc-alkaline rocks in terms of $\mathrm{Sr}-\mathrm{Nd}$ isotope compositions. This isotopic similarity strongly suggests a common magma source between the Cretaceous Gangdese arc rocks and later adakites. Formation of large batholiths like the ones in the Andes (e.g., Petford and Atherton, 1996) or California (e.g., Ducea, 2001), and the Gangdese (Chu, 2006; Wen, 2007), has generally been attributed to melting of hydrous, underplated basaltic rocks at lower crust levels that may best account for the voluminous silicic rocks formed. This scenario is actually in good consistency with the isotope data (Fig. 9). As shown by the mixing calculation, the Gangdese adakites can be generated by melting of a Gangdese gabbro representing the mafic lower crust, with $\varepsilon_{\mathrm{Nd}}(T)$ value of +3.7 and ${ }^{87} \mathrm{Sr} /{ }^{86} \mathrm{Sr}_{i}$ of 0.70435 , accompanied by small degrees $(<2 \%$, or $\sim 5 \%$ at most) of contamination by the upper continental crust during magma ascent. We therefore propose that the Gangdese adakites were derived from melting of a newly underplated, and then thickened, basaltic lower crust above the mantle wedge in the Neo-Tethyan subduction zone. Considering that there are three grains of detrital zircons dated at ca. $100 \mathrm{Ma}$ in sample T027 (Table 1), broadly coeval to the emplacement age of a granite body of ca. 103 Ma near Langxian (Fig. 1; data from Wen et al., in press), we further argue the basaltic magma underplating to have taken place since ca. $100 \mathrm{Ma}$ or the early Late Cretaceous associated with the Gangdese calc-alkaline magmatism. Subsequent thickening and partial melting of the crust to form the adakitic intrusion are ascribed to a flat-slab stage of the Neo-Tethyan subduction (see below).

\subsection{Trace element modeling of magma generation}

Generation of the Gangdese adakites by melting the newly underplated, thickened mafic lower crust, which could be of eclogite or garnet amphibolite composition (Rapp et al., 1991; Chung et al., 2003), may be modeled using specific element pairs such as $\mathrm{La} / \mathrm{Yb}$ and $\mathrm{Sr} / \mathrm{Y}$ (Fig. 8). With garnet being a residual phase in the melting regime, the magma generation must have occurred at high-pressure or deep crustal levels ( $\geq 1.2 \mathrm{GPa}$ or $40 \mathrm{~km}$; Rapp et al., 1991). Considering the mildly flattened HREE patterns observed in most samples (Fig. 6), which implies amphibole to have played a more important role than garnet during partial melting, garnet amphibolite rather than eclogite is more likely to be the source lithology.

In the $\mathrm{La} / \mathrm{Yb}$ vs. Yb modeling calculation (Fig. 8b), the composition of a Gangdese gabbro (i.e., sample T036B, used also for the Sr-Nd mixing calculation) was utilized as the "starting material" representative of basaltic underplate that transformed to a garnet-bearing amphibolite in the thickened lower crust before partial melting. The modeling results show that the Gangdese adakites can be generated by $\sim 10-20 \%$ melting of the presumed garnet amphibolite with its garnet constituents varying from $\sim 3$ to $15 \%$ (Fig. $8 \mathrm{~b}$ ). In this modeling the $(\mathrm{La} / \mathrm{Yb})_{\mathrm{N}}$ and $\mathrm{Yb}_{\mathrm{N}}$ correlation seems better interpreted in terms of combined variations in both the garnet constituents and the melting degrees. Note that eclogite melting was also modeled and the result does not match with the data (Fig. 8b).

\subsection{Deep-seated emplacement followed by rapid exhumation}

It has been well documented that magmatic epidote crystallizes in granitic magmas only at pressure $\geq 0.6-0.8 \mathrm{GPa}$ (Zen and Hammastrom, 1984; Schmidt and Poli, 2004). Plutonic rocks bearing magmatic epidote, hence, must have formed under even higher pressure that corresponds to lower crustal levels. Celadonitic muscovite is also sensitive to the pressure of crystallization, and thus can be used to estimate the depth of magma emplacement using phengite geobarometry (Massonne and Schreyer, 1987; Anderson, 1996) in combination with zircon saturation thermometry (Watson and Harrison, 1983). Accordingly, we calculated the emplacement P-T conditions for the 
Table 5

Geochemical data of the ca. 80 Ma Gangdese granitoids from Southern Tibet

\begin{tabular}{|c|c|c|c|c|c|c|c|c|c|}
\hline Sample & T212 & T027 & $\mathrm{T} 213$ & $\mathrm{~T} 215$ & T026 & T216A & T217 & T024 & $\mathrm{T} 218 \mathrm{~B}$ \\
\hline Locality & Langxian & Langxian & Langxian & Langxian & Langxian & Lilong & Lilong & Lilong & Lilong \\
\hline Longtitude & $93.31^{\circ} \mathrm{E}$ & $93.32^{\circ} \mathrm{E}$ & $93.34^{\circ} \mathrm{E}$ & $93.41^{\circ} \mathrm{E}$ & $93.44^{\circ} \mathrm{E}$ & $93.61^{\circ} \mathrm{E}$ & $93.64^{\circ} \mathrm{E}$ & $93.75^{\circ} \mathrm{E}$ & $93.75^{\circ} \mathrm{E}$ \\
\hline Latitude & $29.00^{\circ} \mathrm{N}$ & $29.00^{\circ} \mathrm{N}$ & $29.04^{\circ} \mathrm{N}$ & $29.10^{\circ} \mathrm{N}$ & $29.12^{\circ} \mathrm{N}$ & $29.17^{\circ} \mathrm{N}$ & $29.14^{\circ} \mathrm{N}$ & $29.14^{\circ} \mathrm{N}$ & $29.14^{\circ} \mathrm{N}$ \\
\hline Altitude (m) & 3059 & 3092 & 3074 & 3039 & 3014 & 3006 & 3023 & 3022 & 3065 \\
\hline Age (Ma) & & $82.7 \pm 1.6$ & & & & & & $80.4 \pm 1.1$ & \\
\hline \multicolumn{10}{|l|}{$(w t . \%)$} \\
\hline $\mathrm{SiO}_{2}$ & 65.93 & 66.45 & 65.07 & 68.28 & 70.11 & 67.89 & 68.78 & 69.53 & 67.79 \\
\hline $\mathrm{TiO}_{2}$ & 0.36 & 0.36 & 0.36 & 0.24 & 0.16 & 0.30 & 0.23 & 0.26 & 0.29 \\
\hline $\mathrm{Al}_{2} \mathrm{O}_{3}$ & 16.56 & 16.57 & 18.04 & 17.20 & 15.95 & 17.04 & 17.59 & 17.65 & 16.96 \\
\hline $\mathrm{FeO}^{*}$ & 3.16 & 2.87 & 3.43 & 2.14 & 1.41 & 2.52 & 1.83 & 2.22 & 2.50 \\
\hline $\mathrm{MnO}$ & 0.07 & 0.09 & 0.11 & 0.06 & 0.04 & 0.05 & 0.06 & 0.07 & 0.06 \\
\hline $\mathrm{MgO}$ & 0.95 & 0.83 & 1.00 & 0.49 & 0.32 & 0.61 & 0.44 & 0.58 & 0.63 \\
\hline $\mathrm{CaO}$ & 3.35 & 3.83 & 4.40 & 3.21 & 2.61 & 3.44 & 3.32 & 3.54 & 3.45 \\
\hline $\mathrm{Na}_{2} \mathrm{O}$ & 3.68 & 4.13 & 4.18 & 4.48 & 4.38 & 4.46 & 4.46 & 4.41 & 4.26 \\
\hline $\mathrm{K}_{2} \mathrm{O}$ & 2.97 & 1.84 & 2.12 & 2.09 & 2.20 & 1.82 & 2.10 & 1.73 & 2.15 \\
\hline $\mathrm{P}_{2} \mathrm{O}_{5}$ & 0.13 & 0.14 & 0.14 & 0.06 & 0.04 & 0.08 & 0.06 & 0.10 & 0.09 \\
\hline $\mathrm{A} / \mathrm{CNK}$ & 1.08 & 1.05 & 1.05 & 1.11 & 1.11 & 1.09 & 1.12 & 1.13 & 1.09 \\
\hline Mg\# & 37 & 36 & 37 & 31 & 31 & 32 & 32 & 34 & 33 \\
\hline \multicolumn{10}{|l|}{ (ppm) } \\
\hline Sc & 10.2 & 7.3 & 9.4 & 10.1 & 3.0 & 6.9 & 9.9 & 6.1 & 7.2 \\
\hline V & 4.4 & 32.4 & n.d. & n.d. & 87.7 & n.d. & n.d. & 11.8 & n.d. \\
\hline $\mathrm{Cr}$ & 0.19 & 9.07 & n.d. & n.d. & 4.45 & n.d. & n.d. & 11.40 & n.d. \\
\hline Mn & 506 & 625 & 728 & 462 & 360 & 400 & 410 & 520 & 457 \\
\hline Co & 4.1 & 4.4 & 4.4 & 2.0 & 1.6 & 2.5 & 1.9 & 3.1 & 2.7 \\
\hline $\mathrm{Ni}$ & 1.6 & 5.2 & 1.1 & 0.4 & 1.2 & 0.4 & 0.7 & 5.8 & 0.5 \\
\hline $\mathrm{Cu}$ & 37.0 & 558.5 & 15.1 & 8.4 & 11.5 & 5.5 & 8.6 & 28.1 & 12.5 \\
\hline $\mathrm{Zn}$ & 53.4 & 60.9 & 62.4 & 49.0 & 42.2 & 46.7 & 44.3 & 51.2 & 49.3 \\
\hline $\mathrm{Ga}$ & 18.7 & 17.3 & 18.5 & 17.9 & 16.0 & 17.8 & 18.2 & 19.6 & 17.7 \\
\hline $\mathrm{Rb}$ & 90.3 & 41.3 & 45.1 & 54.5 & 53.3 & 35.9 & 49.9 & 40.9 & 42.6 \\
\hline $\mathrm{Sr}$ & 622 & 622 & 688 & 757 & 626 & 768 & 780 & 738 & 719 \\
\hline $\mathrm{Y}$ & 9.9 & 9.3 & 11.6 & 6.8 & 9.1 & 4.1 & 7.1 & 5.0 & 5.0 \\
\hline $\mathrm{Zr}$ & 120 & 106 & 102 & 137 & 135 & 139 & 122 & 139 & 117 \\
\hline $\mathrm{Nb}$ & 5.22 & 4.95 & 3.73 & 3.31 & 3.07 & 2.97 & 3.46 & 4.05 & 2.79 \\
\hline Cs & 3.87 & 1.32 & 1.73 & 2.86 & 1.52 & 0.82 & 1.41 & 0.77 & 0.82 \\
\hline $\mathrm{Ba}$ & 492 & 407 & 479 & 534 & 619 & 462 & 534 & 461 & 600 \\
\hline La & 21.5 & 18.3 & 16.2 & 22.2 & 26.5 & 21.2 & 19.6 & 14.9 & 13.5 \\
\hline $\mathrm{Ce}$ & 36.3 & 35.4 & 27.5 & 35.4 & 49.2 & 33.7 & 31.3 & 27.3 & 21.7 \\
\hline $\mathrm{Pr}$ & 4.53 & 3.95 & 3.60 & 4.17 & 5.04 & 4.06 & 3.77 & 2.90 & 2.61 \\
\hline $\mathrm{Nd}$ & 16.80 & 14.41 & 13.92 & 14.53 & 17.61 & 14.41 & 13.25 & 10.23 & 9.44 \\
\hline $\mathrm{Sm}$ & 3.03 & 2.51 & 2.68 & 2.09 & 2.61 & 2.23 & 2.17 & 1.62 & 1.63 \\
\hline $\mathrm{Eu}$ & 0.81 & 0.81 & 0.79 & 0.68 & 0.68 & 0.71 & 0.67 & 0.52 & 0.66 \\
\hline Gd & 2.30 & 2.02 & 2.15 & 1.50 & 1.91 & 1.56 & 1.66 & 1.27 & 1.31 \\
\hline $\mathrm{Tb}$ & 0.33 & 0.28 & 0.33 & 0.17 & 0.27 & 0.19 & 0.23 & 0.15 & 0.18 \\
\hline Dy & 1.69 & 1.54 & 1.88 & 0.85 & 1.31 & 0.81 & 1.20 & 0.82 & 0.89 \\
\hline Ho & 0.31 & 0.30 & 0.36 & 0.18 & 0.27 & 0.14 & 0.22 & 0.16 & 0.16 \\
\hline $\mathrm{Er}$ & 0.86 & 0.87 & 1.05 & 0.63 & 0.84 & 0.38 & 0.62 & 0.45 & 0.43 \\
\hline $\mathrm{Tm}$ & 0.13 & 0.13 & 0.17 & 0.11 & 0.14 & 0.05 & 0.09 & 0.06 & 0.06 \\
\hline $\mathrm{Yb}$ & 0.79 & 0.94 & 1.11 & 0.72 & 0.95 & 0.36 & 0.59 & 0.45 & 0.38 \\
\hline $\mathrm{Lu}$ & 0.13 & 0.15 & 0.18 & 0.11 & 0.16 & 0.06 & 0.10 & 0.07 & 0.06 \\
\hline $\mathrm{Hf}$ & 3.23 & 2.98 & 2.87 & 3.48 & 3.44 & 3.43 & 3.12 & 3.63 & 2.89 \\
\hline Та & 0.42 & 0.36 & 0.33 & 0.27 & 0.24 & 0.14 & 0.20 & 0.18 & 0.10 \\
\hline $\mathrm{Pb}$ & 13.7 & 12.4 & 16.2 & 16.5 & 17.8 & 14.9 & 18.7 & 16.9 & 14.5 \\
\hline Th & 6.95 & 3.45 & 5.29 & 4.06 & 6.69 & 4.03 & 4.21 & 2.38 & 1.84 \\
\hline $\mathrm{U}$ & 1.79 & 0.87 & 1.60 & 0.54 & 0.83 & 0.38 & 0.57 & 0.41 & 0.38 \\
\hline $\mathrm{Sr} / \mathrm{Y}$ & 62.7 & 66.9 & 59.5 & 111.8 & 69.0 & 189.4 & 110.1 & 148.3 & 143.8 \\
\hline$(\mathrm{La} / \mathrm{Yb})_{\mathrm{N}}$ & 19.5 & 14.0 & 10.4 & 21.9 & 20.0 & 42.1 & 23.7 & 23.7 & 25.1 \\
\hline${ }^{87} \mathrm{Sr} /{ }^{86} \mathrm{Sr}$ & 0.705239 & 0.704720 & 0.704591 & 0.704700 & 0.704693 & 0.704525 & 0.704655 & 0.704562 & 0.704581 \\
\hline${ }^{87} \mathrm{Sr} /{ }^{86} \mathrm{Sr}_{i}$ & 0.7048 & 0.7045 & 0.7044 & 0.7045 & 0.7044 & 0.7044 & 0.7044 & 0.7044 & 0.7044 \\
\hline${ }^{143} \mathrm{Nd} /{ }^{144} \mathrm{Nd}$ & 0.512637 & 0.512699 & 0.512748 & 0.512664 & 0.512747 & 0.512706 & 0.512673 & 0.512702 & 0.512709 \\
\hline${ }^{143} \mathrm{Nd} /{ }^{144} \mathrm{Nd}_{\mathrm{i}}$ & 0.51258 & 0.51264 & 0.51269 & 0.51262 & 0.51270 & 0.51266 & 0.51262 & 0.51265 & 0.51265 \\
\hline$\varepsilon_{\mathrm{Nd}}(\mathrm{T})$ & 0.9 & 2.2 & 3.0 & 1.6 & 3.2 & 2.4 & 1.7 & 2.3 & 2.3 \\
\hline $\mathrm{T}_{\mathrm{DM}}(\mathrm{Ga})$ & 0.75 & 0.64 & 0.63 & 0.59 & 0.51 & 0.56 & 0.64 & 0.58 & 0.62 \\
\hline $\mathrm{T}_{\mathrm{Zr}}\left({ }^{\circ} \mathrm{C}\right)$ & 741 & 730 & 724 & 760 & 761 & 758 & 752 & 765 & 744 \\
\hline
\end{tabular}

*: total Fe, $\mathrm{A} / \mathrm{CNK}$ : molar $\mathrm{Al}_{2} \mathrm{O}_{3} /\left(\mathrm{CaO}+\mathrm{Na}_{2} \mathrm{O}+\mathrm{K}_{2} \mathrm{O}\right), \mathrm{Mg} \#=100(\mathrm{Mg} / \mathrm{Mg}+\mathrm{Fe})$, n.d.: not determined.

${ }^{87} \mathrm{Sr} /{ }^{86} \mathrm{Sr}_{i}={ }^{87} \mathrm{Sr} /{ }^{86} \mathrm{Sr}-\left({ }^{87} \mathrm{Rb} /{ }^{86} \mathrm{Sr}\right) \times\left(e^{\lambda T}-1\right), \lambda_{\mathrm{Rb}-\mathrm{Sr}}=0.0142 \mathrm{Ga}-1,{ }^{87} \mathrm{Rb} /{ }^{86} \mathrm{Sr}=(\mathrm{Rb} / \mathrm{Sr}) \times 2.8956$.

${ }^{143} \mathrm{Nd} /{ }^{144} \mathrm{Nd}_{i}={ }^{143} \mathrm{Nd} /{ }^{144} \mathrm{Nd}-\left({ }^{147} \mathrm{Sm} /{ }^{144} \mathrm{Nd}\right) \times\left(e^{\lambda T}-1\right), \lambda_{\mathrm{Sm}-\mathrm{Nd}}=0.00654 \mathrm{Ga}^{-1},{ }^{147} \mathrm{Sm} /{ }^{144} \mathrm{Nd}=(\mathrm{Sm} / \mathrm{Nd}) \times 0.60456$.

$\varepsilon_{\mathrm{Nd}}(T)=\left[\left({ }^{143} \mathrm{Nd} /{ }^{144} \mathrm{Nd}\right)_{\text {Sample }}(T) /\left({ }^{143} \mathrm{Nd} /{ }^{144} \mathrm{Nd}\right)_{\mathrm{CHUR}}(\mathrm{T})-1\right] \times 10^{4},\left({ }^{143} \mathrm{Nd} /{ }^{144} \mathrm{Nd}\right)_{\mathrm{CHUR}}(T)=0.512638-0.1967 \times\left(\varepsilon^{\lambda \mathrm{T}}-1\right)$.

$T_{\text {DM }}(\mathrm{Ga})=1 / \lambda_{\mathrm{Sm}-\mathrm{Nd}} \times \operatorname{In}\left\{1+\left[\left(\left({ }^{143} \mathrm{Nd} /{ }^{144} \mathrm{Nd}\right)_{\text {Sample }}-0.51315\right) /\left(\left({ }^{147} \mathrm{Sm} /{ }^{144} \mathrm{Nd}\right)_{\text {Sample }}-0.2137\right)\right]\right\}$

Samples not dated are calculated with an age $(T)$ of $80 \mathrm{Ma}$.

$T_{\mathrm{Zr}}\left({ }^{\circ} \mathrm{C}\right)$ : zircon saturation temperature calculated by using the Watson and Harrison (1983) thermometer. 


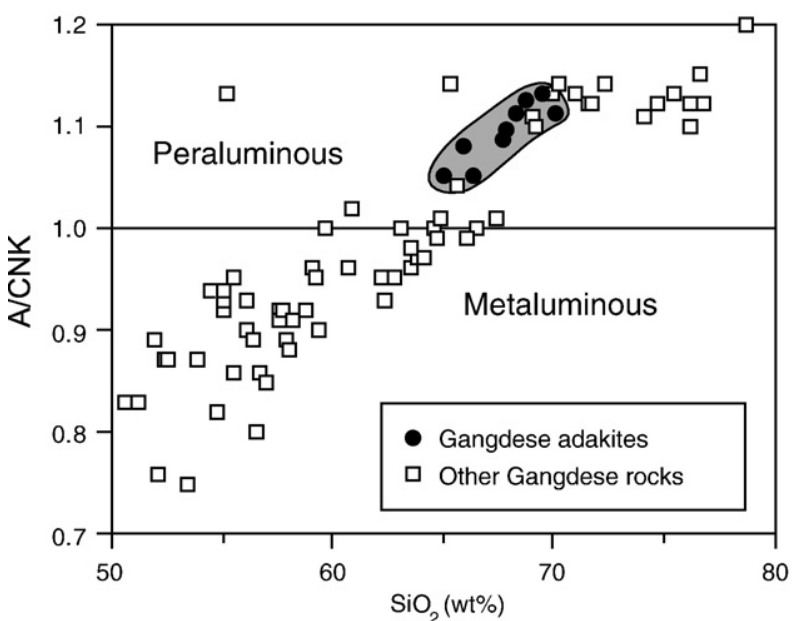

Fig. 5. $\mathrm{A} / \mathrm{CNK}\left[\right.$ molar $\left.\mathrm{Al}_{2} \mathrm{O}_{3} /\left(\mathrm{CaO}+\mathrm{Na}_{2} \mathrm{O}+\mathrm{K}_{2} \mathrm{O}\right)\right]$ vs. $\mathrm{SiO}_{2}$ diagram. Comparison data of the Gangdese batholithic rocks are from Wen (2007).

Gangdese adakites, yielding temperatures from 765 to $724^{\circ} \mathrm{C}$ (Table 5 ) and pressures at $0.85 \pm 0.09(1 \sigma) \mathrm{GPa}$ (from $\sim 1.1$ to $0.66 \mathrm{GPa}$ ). These estimates suggest that the magmas were emplaced around $~ 30$ $25 \mathrm{~km}$ depths under which epidote and muscovite crystallized at $\sim 750{ }^{\circ} \mathrm{C}$ near the solidus temperature.

The occurrence of subhedral epidote/muscovite crystals requires not only deep-seated emplacement but also a following rapid upward transport, otherwise the euhedral crystals cannot survive from complete dissolution by quartzo-feldspathic matrix if slow cooling took place (Zen, 1985; Brandon et al., 1996; Sial et al., 1999; Schmidt and Poli, 2004). Petrographic evidence supporting such a rapid upward transport, and fast cooling, is recorded as the disequilibrium texture (partial dissolution and resorption) surrounding the epidote, muscovite and plagioclase crystals (Fig. 3). This, as exemplified by the North American Cordillera (Ducea, 2001; Saleeby, 2003), may have been affiliated with tectonic uplift and exhumation that could expose mid-crustal ( 25-30 km) batholithic rocks with a rate as fast as 2$3 \mathrm{~mm} / \mathrm{yr}$ during the early Laramide orogeny (Kidder et al., 2003).

\subsection{Implications for flat subduction and regional tectonics}

Based on zircon $\mathrm{U}-\mathrm{Pb}$ age data, Wen et al. (in press) demonstrated that the Gangdese magmatism was active in the Late Cretaceous (ca. 103-80 Ma) and early Paleogene (ca. 68-43 Ma), with a magmatic gap or quiescent period that existed between ca. 80 and $68 \mathrm{Ma}$. It is furthermore proposed that, following a "normal-angle" subduction that resulted in the extensive Cretaceous Gangdese intrusions during ca. 100 and $85 \mathrm{Ma}$, a "flat-slab" stage of Neo-Tethyan subduction

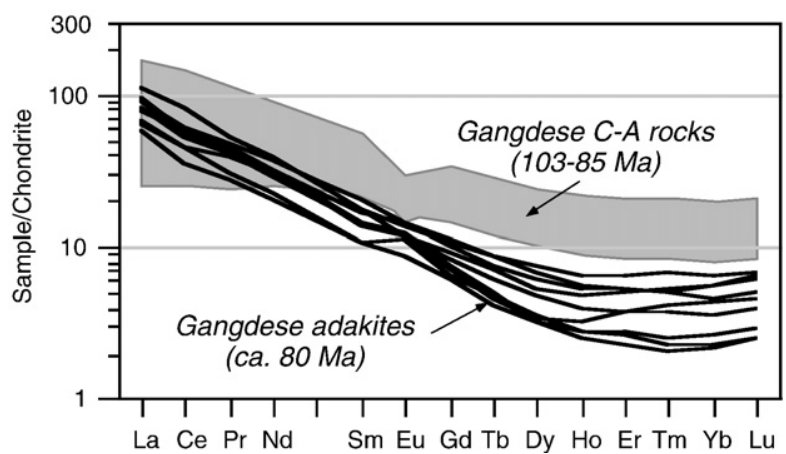

Fig. 6. Chondrite-normalized REE variation diagram. Normalizing values are from Sun and McDonoud (1989). The Cretaceous Gangdese calc-alkaline rocks plotted for comparison are from Wen (2007).

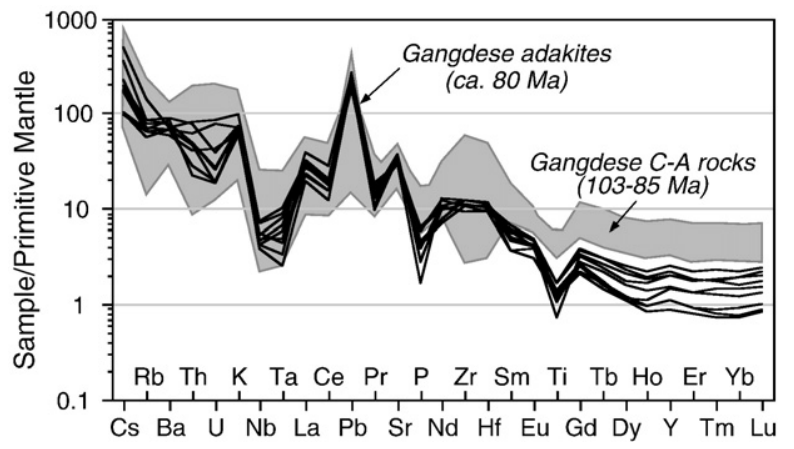

Fig. 7. Primitive mantle-normalized trace element variation diagram. Normalizing values are from Sun and McDonoud (1989). The Cretaceous Gangdese calc-alkaline rocks plotted for comparison are from Wen (2007).

occurred so that led to a contractional tectonic regime lasting until the end-Cretaceous in southern Tibet. Exemplary analogues quoted are the Central Andes (Kay and Mpodozis, 2001) and the Late Cretaceous Laramide orogeny in southern North America (Saleeby, 2003), in both cases flattening of subducting slab has been postulated to not only tectonically thicken the arc crust but also squeeze out the mantle wedge, thus terminating the arc magmatism with adakites being generated in the ending phase (Kay and Mpodozis, 2001; Booker et al.,
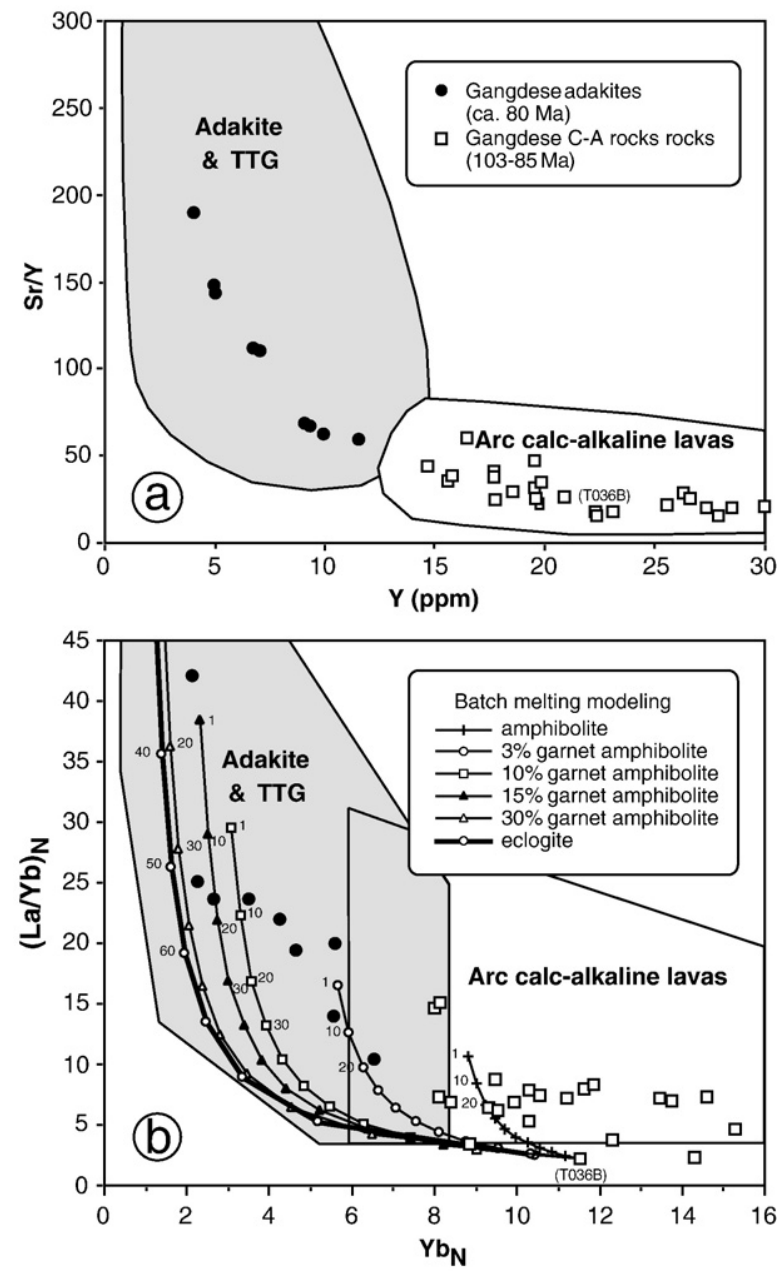

Fig. 8. Plots of (a) Sr/Y vs. Y and (b) chondrite-normalized La/Yb ratios vs. Yb. Fields of adakite and TTG and arc calc-alkaline lavas are from Martin (1999). In (b) a Gangdese gabbro T036B (ca. $102 \mathrm{Ma}$; Wen et al., in press) was utilized as the source rock for the REE modeling under amphibolite and eclogite conditions, with various garnet contents and respective partition coefficients proposed by Irving and Frey (1978), Fujimaki et al. (1984) and Sisson (1994). 


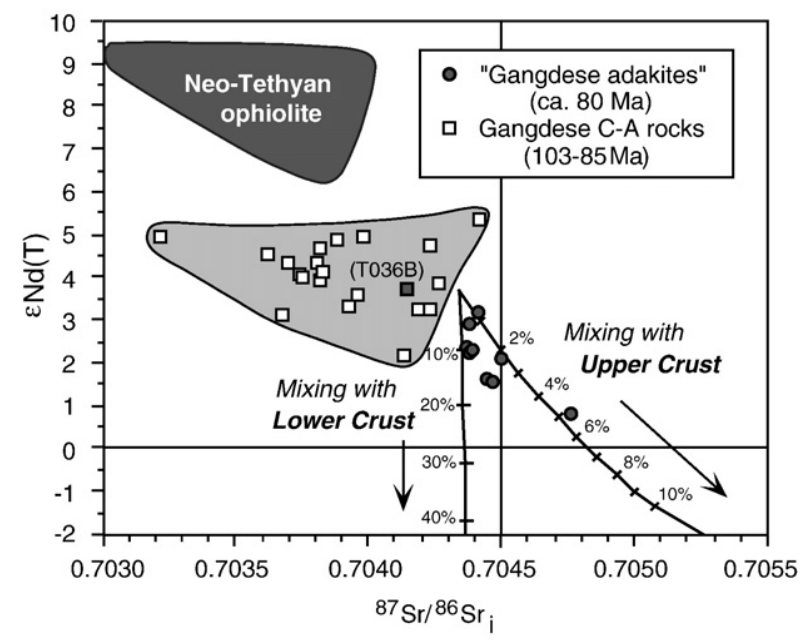

Fig. 9. Sr-Nd isotope correlation diagram of the Gangdese adakites. Field of the NeoTethyan ophiolites from the Yarlu Tsangpo suture representative of the subducted oceanic crust is constructed using the data reported by Xu and Castillo (2004) and Zhang et al. (2005). The upper crust (UC) and lower crust (LC) mixing curves are constructed using the following end-member parameters: (1) a Gangdese gabbro [sample T036B: $\varepsilon_{\mathrm{Nd}}(T)=+3.7,{ }^{87} \mathrm{Sr} /{ }^{86} \mathrm{Sr}_{\mathrm{i}}=0.70435$ ]; (2) UC: $\varepsilon_{\mathrm{Nd}}(T)=-10.2,{ }^{87} \mathrm{Sr}$ ${ }^{86} \mathrm{Sr}_{\mathrm{i}}=0.7123, \mathrm{Nd}=59.2 \mathrm{ppm}, \mathrm{Sr}=315 \mathrm{ppm}$; and (3) LC: $\varepsilon_{\mathrm{Nd}}(T)=-10.2,{ }^{87} \mathrm{Sr}$ ${ }^{86} \mathrm{Sr}_{\mathrm{i}}=0.7044, \mathrm{Nd}=11 \mathrm{ppm}, \mathrm{Sr}=348 \mathrm{ppm}$. All these and Gangdese data are from Wen (2007) except the Sr and Nd concentrations of the LC component are assumed values from Rudnick and Gao (2003).

2004). Mimicking scenarios are observed in southern Tibet where the Cretaceous stage of Gangdese intrusions ceased with adakitic activity followed by a magmatic gap. Wen et al. (in press), therefore, argued that the region underwent a combined magmatic/tectonic thickening of the crust above the mantle wedge, with the former owing to extensive basaltic underplating associated with the Cretaceous Gangdese intrusions and the latter to the proposed flat subduction. In the Andes, flat subduction occurs when oceanic plateau, ridge or seamount is being subducted (cf. Gutscher et al., 2000). Within the Neo-Tethys Ocean, similar structural features should have been common because their remnants have been widely identified along the Yarlu Tsangpo suture zone (Aitchison et al., 2004; Dubois-Cote et al., 2005; Dupuis et al., 2005).

This flat subduction model explains not only the magmatic evolution but also the Late Cretaceous crustal deformation and shortening in the Lhasa terrane (England and Searle, 1986; Coulon et al., 1986; Ratschbacher et al., 1993; Murphy et al., 1997; Yin and Harrison, 2000). The Cretaceous Takena Formation, for example, stopped deposition at ca. 90-80 Ma and experienced a period of folding and erosion from ca. 80 to $70 \mathrm{Ma}$, before the restart of nonmarine deposition accompanied by the Paleogene Linzizong volcanism (Leier et al., 2007). These can be interpreted as the consequence of an Andean- or "Pacific-type" accretionary orogeny (Maruyama, 1997) that happened in southern Tibet at this specific time span owing to the flat subduction. Analogous to the Central Andes that shows high surface elevations associated with thick crust and a welldeveloped fold-and-thrust belt in the retroarc region (cf. Kay and Mpodozis, 2001), it is rational to further argue that a high, but relatively narrow, mountain range existed in southern Tibet during the Late Cretaceous. In other words, southern Tibet was situated in an accretionary convergent margin where subduction-related orogenic processes involving arc magmatism, crustal thickening and rapid tectonic uplift had been operating actively prior to the collision of India with this particular part of Asia.

\section{Acknowledgments}

We thank Q. Zhang, T.-Y. Lee, C.-H. Lo, H.-Y. Lee and Q. Qian for assistance in the field, H.-M. Li, M.-F. Chu and H. Tao for help with zircon dating experiments, C.-Y. Lee and C.-H. Chu for help with XRF and ICP-MS analyses, L.-Y. Huang for help with Sr-Nd isotope measurements, and two anonymous reviewers for constructive journal reviews. This work benefited from research supports by the National Science Council, Taiwan, ROC.

\section{References}

Aitchison, J.C., Davis, A.M., Ali, J.R., et al., 2004. Stratigraphic and sedimentary constraints on the age and tectonic evolution of the Neotethyan ophiolites along the Yarlung Tsangpo suture zone, Tibet. In: Dilek, Y., et al. (Ed.), Ophiolites in Earth History. . Special Publication, vol. 218. Geological Society, London, pp. 147-164.

Allegrè, C.J., Courtillot, V., Tapponnier, P., et al., 1984. Structure and evolution of the Himalaya-Tibet orogenic belt. Nature 307, 17-22.

Anderson, J.L., 1996. Status of thermobarometry in granitic batholiths. Transactions of the Royal Society of Edinburgh Earth Science 87, 125-138.

Atherton, M.P., Petford, N., 1993. Generation of sodium-rich magmas from newly underplated basaltic crust. Nature $362,144-146$

Barth, A.P., 1990. Mid-crustal emplacement of Mesozoic plutons, San Gabriel Mountains, California, and implications for the geologic history of the San Gabriel terrane. In: Anderson, J.L. (Ed.), The nature and origin of Cordilleran magmatism. . Memoir, vol 174. Geological Society of America, pp. 33-45.

Belousova, E.A., Griffin, W.L., O'Reilly, S.Y., Fisher, N.I., 2002. Igneous zircons: Trace element composition as an indicator of source rock type. Contributions to Mineralogy and Petrology 143, 602-622.

Black, L.P., Kamo, S.L., Williams, I.S., Mundil, R., Davis, D.W., Korsch, R.J., Foudoulis, C., 2003. The application of SHRIMP to phanerozoic geochronology: a critical appraisal of four zircon standards. Chemical Geology 200, 171-188.

Booker, J.R., Favetto, A., Pomposlello, M.C., 2004. Low electrical resistivity associated with plunging of the Nazca flat slab beneath Argentina. Nature 429, 399-403.

Bradon, A.D., Creaser, R.A., Chacko, T., 1996. Constraints on rates of granitic magma transport from epidote dissolution kinetics. Science 271, 1845-1848.

Chappell, B.W., White, A.J.R., 1974. Two contrasting granite types. Pacific Geology 8, $173-174$.

Chu, M.-F., 2006. Application of ICP-MS to the study of Trans-Himalayan petrogenesis. Unpubl. PhD thesis, National Taiwan University.

Chu, M.-F., Chung, S.-L., Song, B., et al., 2006. Zircon U-Pb and Hf isotope constraints on the Mesozoic tectonics and crustal evolution of southern Tibet. Geology 34, 745-748.

Chung, S.-L., Liu, D., Ji, J., Chu, M.-F., Lee, H.-Y., Wen, D.-J., Lo, C.-H., Lee, T.-Y., Qian, Q. Zhang, Q., 2003. Adakite from continental collision zones: melting of thickened lower crust beneath southern Tibet. Geology 31, 1021-1024.

Copeland, P., Harrison, T.M., Pan, Y., Kidd, W.S.F., Roden, M., Zhang, M., 1995. Thermal evolution of the Gangdese batholith, southern Tibet: a history of episodic unroofing. Tectonics 14, 223-236.

Coulon, C., Maluski, H., Bollinger, C., Wang, S., 1986. Mesocoic and Cenozoic volcanic rocks from central and southern Tibet: ${ }^{39} \mathrm{Ar} /{ }^{40} \mathrm{Ar}$ dating, petrological characteristics and geodynamical significance. Earth and Planetary Science Letters 79, 281-302.

Debon, F., Sonet, J., Liu, G.H., Jin, C.W., Xu, R.-H., 1982. Major chemical-mineralogical characters and $\mathrm{Rb}-\mathrm{Sr}$ dating of the three plutonic belts in southern Tibet. Comptes Rendus-Academic Science, Paris 295, 213-218.

Debon, F., Le Fort, P., Sheppard, S.M.F., Sonet, J., 1986. The four plutonic belts of the Transhimalaya-Himalaya: a chemical, mineralogical, isotopic and chronological synthesis along a Tibet-Nepal section. Journal of Petrology 27, 219-250.

Defant, M.J., Drummond, M.S., 1990. Derivation of some modern arc magmas by melting of young subducted lithosphere. Nature 347, 662-665.

Dubois-Cote, V., Hebert, R., Dupuis, C., Wang, C.S., Li, Y.L., Dostal, J., 2005. Petrologic and geochemical evidence for the origin of the Yarlung Zhanbo ophiolites, southern Tibet. Chemical Geology 214, 265-286.

Ducea, M.N., 2001. The California arc: Thick granitic batholiths, eclogitic residues, lithosphere-scale thrusting, and magmatic flare-ups. GSA Today 11, 4-10.

Dupuis, C., et al., 2005. Petrology and geochemistry of mafic rocks from mélange and flysch units adjacent to the Yarlung Zangbo suture zone, southern Tibet. Chemical Geology 214, 287-308.

England, P., Searle, M., 1986. The Cretaceous-Tertiary deformation of the Lhasa block and its implications for crustal thickening in Tibet. Tectonics 5, 1-14.

Fujimaki, H., Tatsumoto, M., Aoki, K., 1984. Partition coefficients of Hf, $\mathrm{Zr}$ and REE between phenocrysts and groundmass. Journal of Geophysical Research 89 662-672.

Guo, Z., Wilson, M., Liu, J., 2007. Post-collisional adakites in south Tibet: products of partial melting of subduction-modified lower crust. Lithos 96, 205-224.

Gütscher, M.-A., Spakman, W., Bijwaard, H., Engdahl, E.R., 2000. Geodynamics of flat subduction: seismicity and tomographic constraints from the Andean margin. Tectonics 19, 814-833.

Harris, N.B.W., Xu, R.-H., Lewis, C.L., Jin, C., 1988. Plutonic rocks of the 1985 Tibet Geotraverse: Lhasa to Golmud. Philosophical Transactions of the Royal Society of London A327, 145-168.

Harris, N.B.W., Inger, S., Xu, R.H., 1990. Cretaceous plutonism in central Tibet: An example of post-collision magmatism? Journal of Volcanology and Geothermal Research 44, 21-32.

Harrison, T.M., Yin, A., Grove, M., et al., 2000. The Zedong Window: a record of superposed Tertiary convergence in southeastern Tibet. Journal of Geophysical Research 105, 19221-19230. 
Hou, Z.Q., Gao, Y.F., Qu, X.M., Rui, Z.Y., Mo, X.X., 2004. Origin of adakitic intrusives generated during mid-Miocene east-west extension in southern Tibet. Earth and Planetary Science Letters 220, 139-155.

Irving, A.J., Frey, F.A., 1978. Distribution of trace elements between garnet megacrysts and host volcanic liquids of kimberlitic to rhyolitic composition. Geochimica et Cosmochimica Acta 42, 771-787.

Jin, C.W., Xu, R.H., 1984. Les granitoïdes de la partie centrale de l'Himalaya et du Gangdise au Xizang (Tibet) méridional. In: Mercier, J.L., Li, G.C. (Eds.), Mission Franco-Chinoise au Tibet 1980, Paris: Cent. Natl. Rech. Science, pp. 289-308.

Kapp, P., Yin, A., Harrison, T.M., Ding, L., 2005. Cretaceous-Tertiary shortening, basin development, and volcanism in central Tibet. Geological Society of America Bulletin $117,865-878$.

Kay, R.W., Kay, S.M., 1993. Delamination and delamination magmatism. Tectonophysics $217,177-189$.

Kay, R.W., Kay, S.M., 2002. Andean adakites: three ways to make them. Acta Petrologica Sinica 18, 303-311.

Kay, S.M., Mpodozis, C., 2001. Central Andean ore deposits linked to evolving shallow subduction systems and thickening crust. GSA Today. 11, 4-9.

Kidder, S., Ducea, M., Gehrels, G., Patchett, P.J., Vervoort, J., 2003. Tectonic and magmatic development of the Salinian Coast Range Belt, California. Tectonics 22, 1058 doi:10.1029/2002TC001409.

Leier, A.L., DeCelles, P.G., Kapp, P., Ding, L., 2007. The Takena Formation of the Lhas terrane, southern Tibet: the record of a Late Cretaceous retroarc foreland basin. Geological Society of America Bulletin 119, 31-48.

Liu, D., Jian, P., Kröner, A., Xu, S., 2006. Dating of prograde metamorphic events deciphered from episodic zircon growth in rocks of the Dabie-Sulu UHP complex China. Earth and Planetary Science Letters 250, 650-666.

Liu, Y.-S., Yang, H.-J., Shau, Y.-H., Meng, F., Zhang, J., Yang, J., Xu, Z., Yu, S.-C., 2007. Compositions of high Fe-Ti eclogites from the Sulu UHP metamorphic terrane, China: HFSE decoupling and protolith characteristics. Chemical Geology 239, 64-82.

Maluski, H., Proust, F., Xiao, X.C., 1982. ${ }^{39} \mathrm{Ar} /{ }^{40} \mathrm{Ar}$ dating of the trans-Himalayan calcalkaline magmatism of southern Tibet. Nature 298, 152-154.

Maruyama, S., 1997. Pacific-type orogeny revisited: Miyashiro-type orogeny proposed. Island Arc 6, 121-142.

Martin, H., 1999. Adakitic magmas: modern analogues of Archean granitoids. Lithos 46, 411-429.

Massonne, H.-J., Schreyer, W., 1987. Phengite geobarometry based on the limiting assemblage with K-feldspar, phlogopite, and quartz. Contributions to Mineralogy and Petrology 96, 212-224.

Mo, X.X., Dong, G., Zhao, Z., et al., 2005. Spatial and temporal distribution and characteristics of granitoids in the Gangdese, Tibet and implication for crustal growth and evolution. Geological Journal of Chinese University 11, 281-190.

Murphy, M.A., Yin, A., Harrison, T.M., Dürr, S.B., Chen, Z., Ryerson, F.J., Kidd, W.S.F., Wang, X., Zhou, X., 1997. Did the Indo-Asian collision alone create the Tibetan plateau? Geology 25, 719-722.

Nelson, S.T., Montana, A., 1992. Sieve-textured plagioclase in volcanic rocks produced by rapid decompression. American Mineralogists 77, 1242-1249.

Petford, N., Atherton, M., 1996. Na-rich partial melts from newly underplated basaltic crust: The Cordillera Blanca batholith, Peru. Journal of Petrology 37, 1491-1521.

Pitcher, W.S., 1982. Granite type and tectonic environment. In: Hsü, K.J. (Ed.), Mountain Building Processes. Academic Press, London, pp. 19-40.

Quidelleur, X., Grove, M., Lovera, O.M., Harrison, T.M., Yin, A., Ryerson, F.J., 1997. Therma evolution and slip history of the Renbu Zedong Thrust, southern Tibet. Journal of Geophysical Research 102, 2659-2679.

Rapp, R.P., Watson, E.B., Miller, C.F., 1991. Partial melting of amphibolite/eclogite and the orgin of Archean trondhjemites and tonalities. Precambrian Research 51,1-25.

Ratschbacher, L., Frisch, W., Chen, C., Pan, G., 1993. Deformation and motion along the southern margin of the Lhasa block (Tibet) prior to and during the India-Asia collision. Journal of Geodynamics 16, 21-54.

Rudnick, R.L., Gao, S., 2003. The composition of the continental crust. In: Holland, A.D., Turekian, K.K. (Eds.), Treatise on Geochemistry, vol. 3. Elsevier-Pergamon, Oxford, pp. 1-64.
Saleeby, J., 2003. Segmentation of the Laramide slab-evidence from the southern Sierra Nevada region. Geological Society of America Bulletin 115, 655-668.

Schärer, U., Xu, R.H., Allègre, C.J., 1984. U-Pb geochronology of the Gangdese (Transhimalaya) plutonism in the Lhasa-Xigaze region, Tibet. Earth and Planetary Science Letters 69, 311-320.

Schmidt, M.W., Poli, S., 2004. Magmatic epidote. In: Schmidt, M.W., Poli, S. (Eds.), Reviews in Mineralogy and Geochemistry, 56, pp. 399-430.

Searle, M.P., Windley, B.F., Coward, M.P., et al., 1987. The closing of Tethys and the tectonics of the Himalaya. Geological Society of America Bulletin 98, 678-701.

Sial, A.N., Toselli, A.J., Saavedra, J., Parada, M.A., Ferreira, V.P., 1999. Emplacement, petrological and magnetic susceptibility characteristics of diverse magmatic epidote-beraring granitoid rocks in Brazil, Argentina and Chile. Lithos 46, 367-392.

Sisson, T.W., 1994. Hornblende-melt trace-element partitioning measured by ion microprobe. Chemical Geology 117, 331-344.

Smithies, R.H., 2000. The Archean tonalite-tronhjemite-granodiorite (TTG) series is not analogue of Cenozoic adakites. Earth and Planetary Science Letters 182, 115-125.

Sun, S.-S., McDonoud, W.F., 1989. Chemical and isotopic systematics of oceanic basalts: implications for mantle composition and processes. In: Saunders, A.D., Norry, M.J. (Eds.), Magmatism in the Ocean Basins. Special Publications, vol. 42. Geological Society, London, pp. 313-345.

TBGMR (Tibetan Bureau of Geology and Mineral Resources), 1993. Regional Geology of Xizang (Tibet) Autonomous Region. Geologic Memoir Ser. 1, vol. 31. Geologic Publication House, Beijing. 699 pp. (in Chinese with English abstract).

Watson, E.B., Harrison, T.M., 1983. Zircon saturation revised: temperature and composition effects in a variety of crustal magma types. Earth and Planetary Science Letters 64, 295-304.

Wen, D.-R., 2007. The Gangdese Batholith, southern Tibet: Ages, geochemical characteristics and petrogenesis. Unpubl. PhD thesis, National Taiwan University.

Wen, D.-J., Chung S.-L, Liu, D, et al, 2003. New SHRIMP U-Pb zircon ages from the Gangdese batholith and implications for the Trans-Himalayan magmatic evolution. Geophysical Research Abstracts 5, 8864.

Wen, D.-J., Song, B., Iizuka, Y., et al., 2004. Discovery of Late cretaceous granodiorites with adakitic geochemical signatures from southern Tibet: Petrogenesis and tectonic implications: Eos Trans. AGU 85 (47), F1817.

Wen, D.-R., Liu, D., Chung, S.-L., Ji, J., Zhang, Q., Song, B., Lee, T.-Y., Yeh, M.-W., Lo, C.-H., in press. New zircon SHRIMP U-Pb ages of the Gangdese batholith and implications for Neotethyan subduction in southern Tibet. Chemical Geology.

$\mathrm{Xu}$, J.-F., Castillo, P.R., 2004. Geochemical and Nd-Pb isotopic characteristics of the Tethyan asthenosphere: Implications for the origin of the Indian Ocean mantle domain. Tectonophysics 393, 9-27.

Xu, R.-H., Schärer, U., Allègre, C.J., 1985. Magmatism and metamorphism in the Lhasa block (Tibet): A geochronological study. Journal of Geology 93, 41-57.

Xu, Y.-G., Ma, J.-L., Huang X.-L., Iizuka, Y., Chung, S.-L., Wang, Y.-B., Wu, X.-Y., 2004. Early Cretaceous gabbroic complex from Yinan, Shandong Province: petrogenesis and mantle domains beneath the North China Craton. International Journal of Earth Sciences 93, 1025-1041.

Yang, J.-H., Chung, S.-L., Wilde, S.A., Wu, F.-Y., Chu, M.-F., Lo, C.-H., Fan, H.-R., 2005. Petrogenesis of post-orogenic syenites in the Sulu Orogenic Belt, East China: Geochronological, geochemical and Nd-Sr isotopic evidence. Chemical Geology 214, 99-125.

Yin, A., Harrison, T.M., 2000. Geologic evolution of the Himalayan-Tibetan orogen. Annual Review of Earth and Planetary Sciences 28, 210-280.

Zhang, S.-Q., Mahoney, J.J., Mo, X.X., Ghazi, A.M., Milani, L., Crawford, A.J., Guo, T.-Y., Zhao, Z.-D., 2005. Evidence for a widespread Tethyan upper mantle with IndianOcean-type isotopic characteristics. Journal of Petrology 46, 829-858.

Zen, E.-A., 1985. Implications of magmatic epidote-bearing plutons on crustal evolution in the accreted terranes of northwestern North America. Geology 13, 266-269.

Zen, E.-A., Hammastrom, J.M., 1984. Magmatic epidote and its petrologic significance. Geology 12, 515-518 